LA-14325

Approved for public release;

distribution is unlimited.

Seismic Fragility of the LANL Fire

Water Distribution System

- Los Alamos 
Los Alamos National Laboratory, an affirmative action/ equal opportunity employer, is operated by Los Alamos National Security, LLC, for the National Nuclear Security Administration of the U.S. Department of Energy under contract DE-AC52-06NA25396.

\section{NASS \\ National Nuclear Security Administration}

This report was prepared as an account of work sponsored by an agency of the U.S. Government. Neither Los Alamos National Security, LLC, the U.S. Government nor any agency thereof, nor any of their employees make any warranty, express or implied, or assume any legal liability or responsibility for the accuracy, completeness, or usefulness of any information, apparatus, product, or process disclosed, or represent that its use would not infringe privately owned rights. Reference herein to any specific commercial product, process, or service by trade name, trademark, manufacturer, or otherwise does not necessarily constitute or imply its endorsement, recommendation, or favoring by Los Alamos National Security, LLC, the U.S. Government, or any agency thereof. The views and opinions of authors expressed herein do not necessarily state or reflect those of Los Alamos National Security, LLC, the U.S. Government, or any agency thereof. Los Alamos National Laboratory strongly supports academic freedom and a researcher's right to publish; as an institution, however, the Laboratory does not endorse the viewpoint of a publication or guarantee its technical correctness. 
LA-14325

Issued: March 2007

Seismic Fragility of the LANL Fire

Water Distribution System

\author{
Greg Mertz \\ Jason Cardon \\ Mike Salmon
}





\section{Contents}

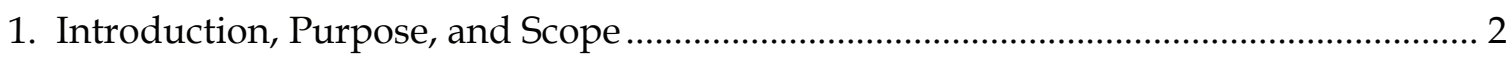

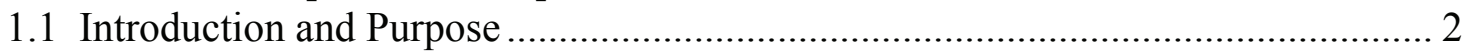

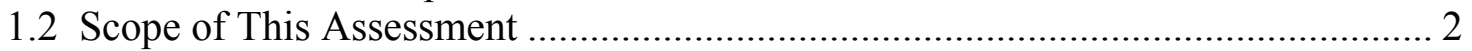

2. Input and Assumptions .................................................................................... 3

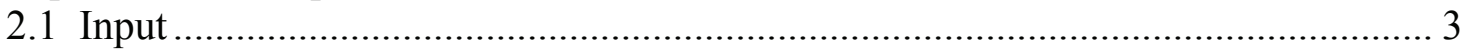

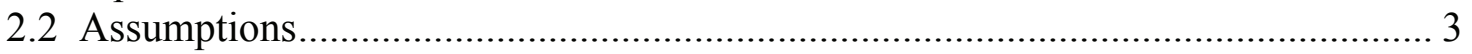

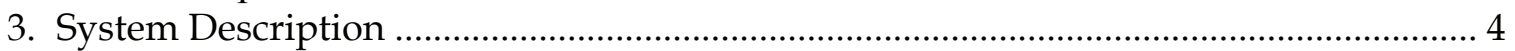

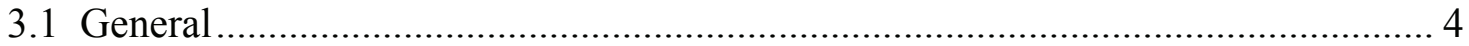

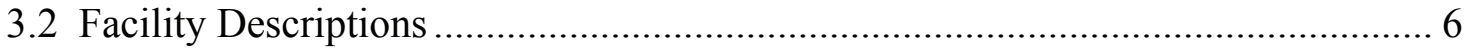

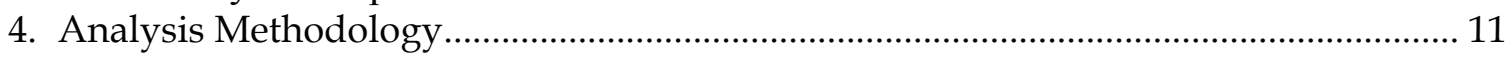

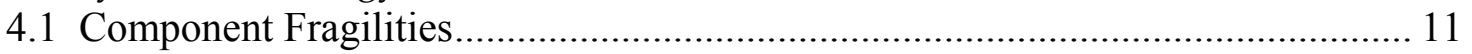

4.2 System Fragility and Probability of Failure ……….......................................... 15

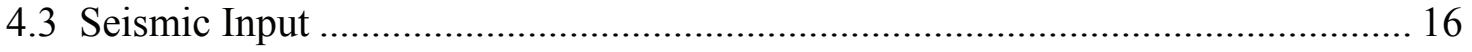

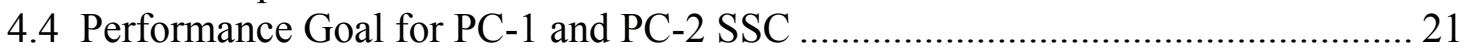

5. Component Failure Frequencies ……………………………………………….... 22

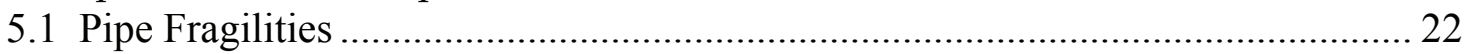

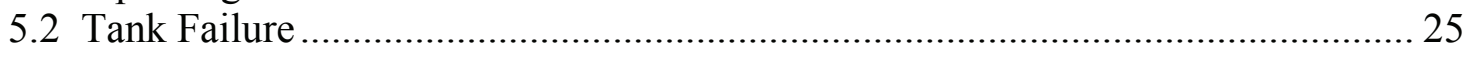

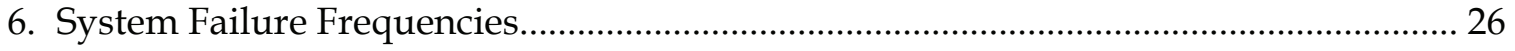

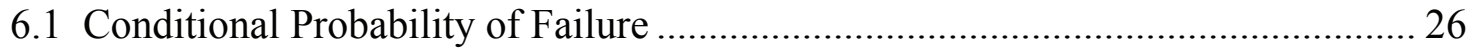

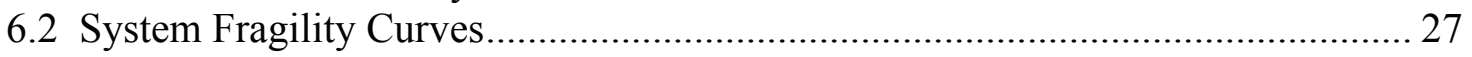

6.3 Annual Probability of Failure ............................................................................ 28

6.4 Reconciliation of Conditional Failure Probability and Annual Failure

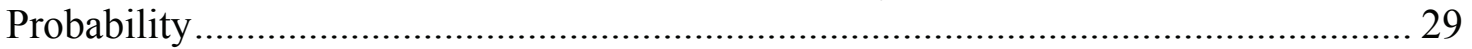

6.5 Potential Impact of the DRAFT 2007 Probabilistic Seismic Hazards Analysis.... 31

7. Summary and Conclusions .................................................................................... 32

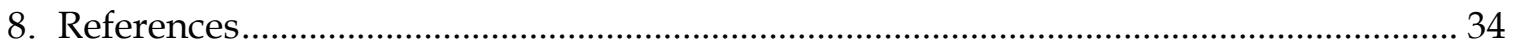




\section{Figures}

Figure 1. Air gap protection-type tank, (note the fill and overflow piping on the right)... 4

Figure 2. Anchored and unanchored tank base details, ............................................... 5

Figure 3. External rigid piping connection (nozzle).................................................. 6

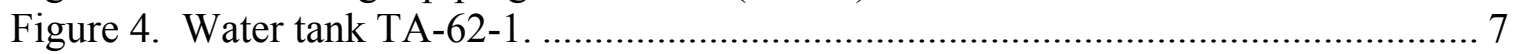

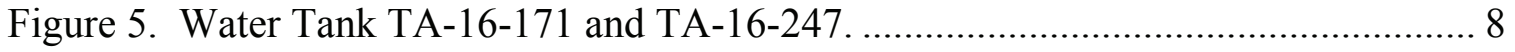

Figure 6. Water tank TA-64-3. ........................................................................... 9

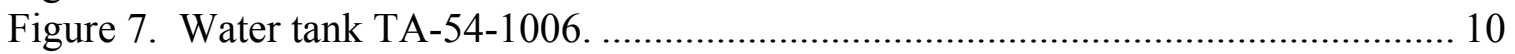

Figure 8. Probability of pipe failure caused by a fault offset...................................... 14

Figure 9. Seismic hazard curves for 0.2-second spectral accelerations at different TAs. 18

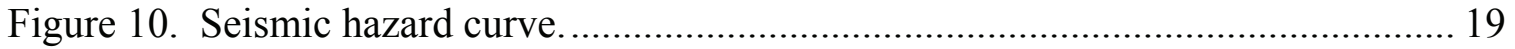

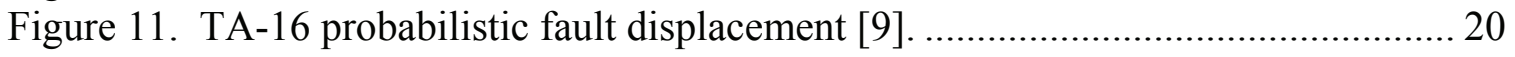

Figure 12. Comparison of hazard curves............................................................. 21

Figure 13. Pipe failure fragility curves due to wave propagation................................ 23

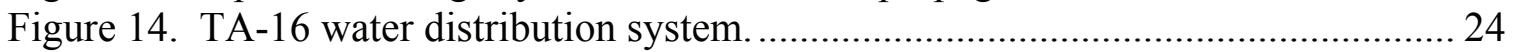

Figure 15. Fragility for unanchored steel tank 100,000 to 2,000,000 gallons ................ 25

Figure 16. Fragility curve for anchored steel tank 100,000 to 2,000,000 gallons

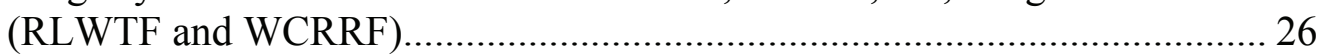

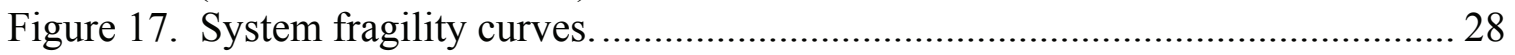

Figure 18. TWISP water distribution system probability density function. ................... 30

Figure 19. Comparison of LANL hazard and $\mathrm{K}_{\mathrm{H}}=4$ hazard. ................................... 31

\section{Tables}

Table 1. Target Water Distribution Acceptance Criteria ............................................... 3

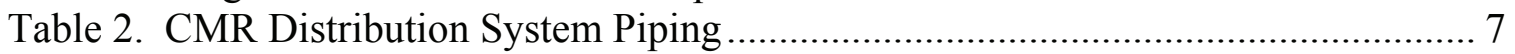

Table 3. WETF Water Distribution System Piping ..................................................... 8

Table 4. RLWTF and WCRRF Distribution System Piping........................................ 9

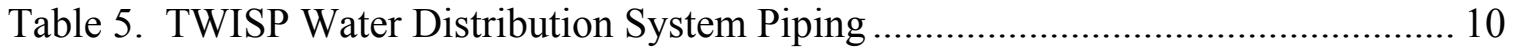

Table 6. Pipe Modification Factors for Wave Propagation ........................................... 12

Table 7. Pipe Modification Factors for Permanent Ground Displacement..................... 12

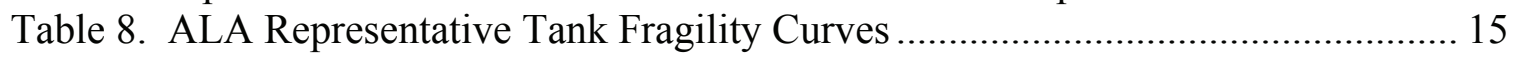

Table 9. Seismic Hazard for Peak Ground Parameters.................................................. 16

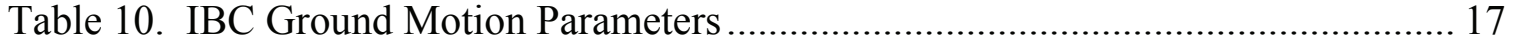

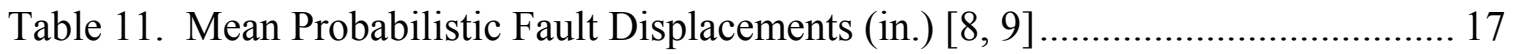

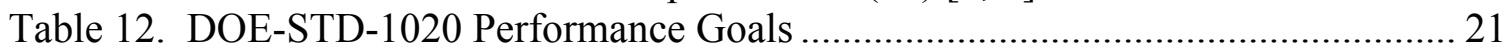

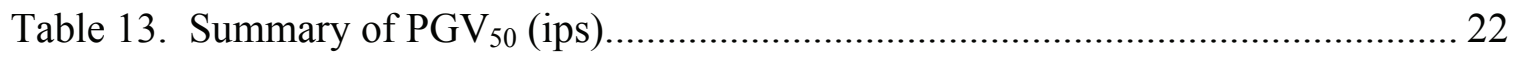

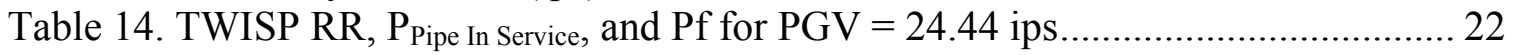

Table 15. Conditional Probability of Water Distribution Piping Failure......................... 23

Table 16. Conditional Probability of Tank Failure...................................................... 24

Table 17. Summary of Conditional Probabilities of Failure .......................................... 27

Table 18. Components for Each System Analyzed ...................................................... 27

Table 19. Summary of Water Distribution System Annual Failure Probabilities .......... 29

Table 20. Summary of Water Distribution System Annual Failure Probabilities ............ 32 


\title{
Seismic Fragility \\ of the \\ LANL Fire Water Distribution System
}

\author{
by \\ Greg Mertz, Jason Cardon, and Mike Salmon
}

\begin{abstract}
The purpose of this report is to present the results of a site-wide system fragility assessment. This assessment focuses solely on the performance of the water distribution systems that supply Chemical and Metallurgy Research (CMR), Weapons Engineering and Tritium Facility (WETF), Radioactive Liquid Waste Treatment Facility (RLWTF), Waste Characterization, Reduction, Repackaging Facility (WCRRF), and Transuranic Waste Inspectable Storage Project (TWISP). The analysis methodology is based on the American Lifelines Alliance ${ }^{1}$ seismic fragility formulations for water systems. System fragilities are convolved with the 1995 LANL seismic hazards to develop failure frequencies. Acceptance is determined by comparing the failure frequencies to the DOE-1020 Performance Goals.

This study concludes that

- If a significant number of existing isolation valves in the water distribution system are closed to dedicate the entire water system ${ }^{2}$ to fighting fires in specific nuclear facilities;

- Then, the water distribution systems for WETF, RLWTF, WCRRF, and TWISP meet the PC-2 performance goal and the water distribution system for CMR is capable of surviving a $0.06 \mathrm{~g}$ earthquake.
\end{abstract}

A parametric study of the WETF water distribution system demonstrates that

- If a significant number of valves in the water distribution system are NOT closed to dedicate the entire water system to fighting fires in WETF;

\footnotetext{
${ }^{1}$ The American Lifelines Alliance is a partnership between the Federal Emergency Management Agency (FEMA), the National Institute of Building Sciences, the Federal Highway Administration (FHwA), Pacific Gas \& Electric Company, ROHN Industries, Inc., the US Geological Survey, and the U.S. Bureau of Reclamation. The American Society of Civil Engineers was also a partner when the seismic fragility formulations for water systems were developed.

${ }^{2}$ The effect of dedicating the entire water supply system to CMR, WETF, RLWTF, WCRRF, and TWISP at the expense of other buildings is not evaluated in this assessment.
} 
- Then, the water distribution system for WETF has an annual probability of failure on the order of $4 \times 10^{-3}$ that does not meet the PC-2 performance goal.

Similar conclusions are expected for CMR, RLWTF, WCRRF, and TWISP.

It is important to note that some of the assumptions made in deriving the results should be verified by personnel in the safety-basis office and may need to be incorporated in technical surveillance requirements in the existing authorization basis documentation if credit for availability of fire protection water is taken at the PC-2 level earthquake levels. Assumptions are presented in Section 2.2 of this report.

\section{Introduction, Purpose, and Scope}

\subsection{Introduction and Purpose}

Five Los Alamos National Laboratory (LANL) nuclear facilities rely on site-supplied water for post-Natural Phenomena Hazards (NPH) event fire suppression [1]. These facilities were identified in a Gap Review of DOE-G-420.1-2 that was performed by the Safety Basis Office [2]. The purpose of this evaluation is to assess whether site-supplied water will be available to these facilities following a seismic event.

In 1998, the Federal Emergency Management Agency (FEMA) and the American Society of Civil Engineers entered into a cooperative agreement to establish the American Lifelines Alliance (ALA) to facilitate the "creation, adoption and implementation of design and retrofit guidelines and other national consensus documents that, when implemented by lifeline owners and operators, will systematically improve the performance of utility and transportation systems to acceptable levels in natural hazard events, including earthquakes." [3] In 2001, the ALA issued Seismic Fragility Formulations for Water Systems [4]—which forms the technical basis for this assessment.

\subsection{Scope of This Assessment}

This memorandum contains an assessment of whether site-supplied water will be available to five selected facilities following a seismic event. The following five facilities, identified in the GAP analysis, are included in the scope of this assessment.

- Chemical and Metallurgy Research (CMR) building located at TA-3,

- Weapons Engineering and Tritium Facility (WETF) at TA-16,

- Radioactive Liquid Waste Treatment Facility (RLWTF) at TA-50,

- Waste Characterization, Reduction, Repackaging Facility (WCRRF) at TA-50, and

- Transuranic Waste Inspectable Storage Project (TWISP) at TA-54. 
The gap analysis identified a sixth facility, Tritium Science and Fabrication Facility (TSFF), which was removed from the scope because of a pending mission change.

The site-supplied portion of the fire-suppression system consists of water storage tanks, distribution piping, hydrants, valves and the Supervisory Control and Data Acquisition (SCADA) system. These components are evaluated probabilistically using the American Lifelines Alliance Seismic Fragility Formulations for Water Systems [4]. System fragilities are convolved with LANL seismic hazards to develop failure frequencies. Acceptances are determined by comparing the failure frequencies to the DOE-1020 Performance Goals [5].

\section{Input and Assumptions}

\subsection{Input}

This assessment is based on the following input:

(1) The facilities required to be evaluated and their respective seismic acceptance criteria are identified in Reference 1 and summarized in Table 1.

(2)Pipe length, diameter, and materials are extracted from AutoCAD drawings of the water distribution provided by Utilities personnel. Water storage tank information has been deduced through the use of schematic drawings provided by KSL, interviews with Utilities personnel, and physical observations. Information concerning site-wide system operations can be found in Reference 6.

(3) Seismic hazard data are from References 7, 8, and 9.

Table 1. Target Water Distribution Acceptance Criteria

\begin{tabular}{|l|c|}
\hline Facility & Acceptance Criteria \\
\hline CMR & 0.06-g Design-Basis Earthquake (DBE) \\
\hline WETF & PC-2 \\
\hline RLWTF & PC-2 \\
\hline WCRRF & PC-2 \\
\hline TWISP & PC-2 \\
\hline
\end{tabular}

\subsection{Assumptions}

This assessment is based on the following assumptions:

(1) In the event of emergency, the water distribution system is assumed to be dedicated to fighting fires at the following nuclear facilities: CMR, WETF, RLWTF, WCRRF, and TWISP.

(2) After the seismic event, emergency personnel will close existing isolation valves on leaking branch lines to dedicate the water supply system to CMR, WETF, RLWTF, WCRRF, and TWISP. Isolation valves on nonleaking branch lines need not be closed.

(3) Emergency personnel will close the required isolation valves fast enough to retain sufficient inventory for the facility's fire-suppression needs. 
(4) Upstream leaks are assumed to be isolated from the first storage tank.

(5) The contents of the first storage tank upstream from the nuclear facility meet all of that facility's fire-suppression needs.

(6) The existing (1995) seismic hazard curves are assumed to accurately represent the site's seismic hazard. An assessment of the potential impact from an updated seismic hazard study is contained in Section 6.5.

Assumptions 1 through 4 minimize the total length of the water distribution system that can leak and minimize the probability of piping failure. Thus, the probability of pipe failure on the far side of available existing isolation valves is omitted from this assessment. Assumption 5 minimizes the probability of tank failure.

\section{System Description}

\subsection{General}

LANL's site-wide water distribution system supplies both the domestic and fireprotection requirements into the same system. The system uses approximately 360 million gallons of water a year, which is supplied by Los Alamos County from wells. There are 19 water storage tanks that provide LANL its water. Distribution of the water is achieved through approximately 100 miles of underground piping.

The LANL water distribution system is gravity fed and can operate without power. Most of the tanks serve as intermediate storage points within the entire system. Some of the tanks are also directly connected to well pump stations. Located at these tanks are booster stations that provide the required pressure to move water from the wells to the tanks.

There are two basic design types of water storage tanks at LANL. The air-gap protection tank uses two separate pipes to fill and discharge the contents of the tank. The fill pipe connects to the top of the tank, but the discharge line is located at the bottom. Below the fill pipe is a full-tank sensor. Should the sensor fail, an overflow pipe is also provided to maintain the air gap. The air gap provides backflow prevention. An air-gap protection tank is shown in Figure 1.

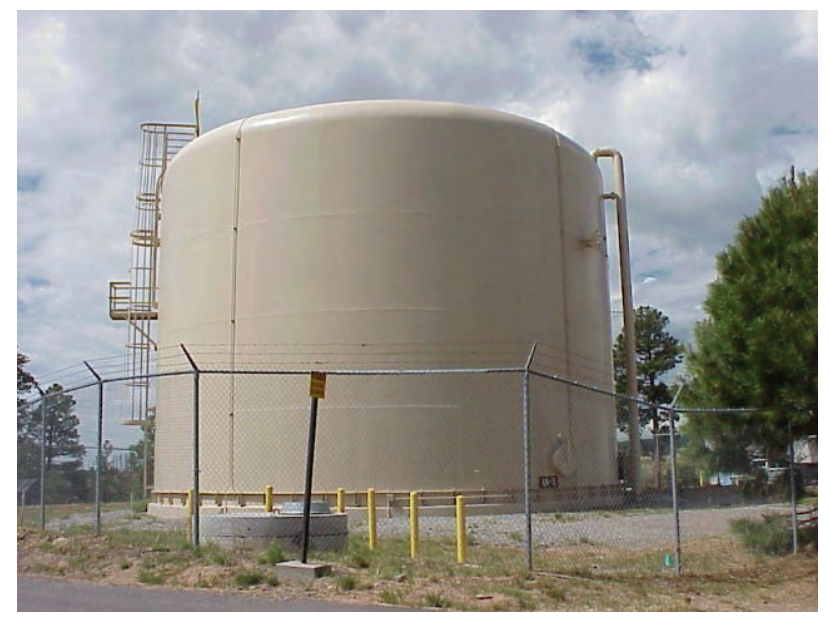

Figure 1. Air gap protection-type tank, (note the fill and overflow piping on the right). 
The other type of tank uses a single pipe, located near the base of the tank, to both fill and discharge the contents. With the single pipe tank design, flow is regulated so that if both the tank and a facility are dependant on that tank and need water, the facility demand takes precedence.

Storage tanks also differ in design by the way they are anchored to the ground. One of the tanks evaluated in this assessment has an anchoring system that restrains the tank from displacement during ground movement. The rest, however, are welded to a metal base plate that rests, unanchored, on top of the concrete foundation pad. These differences are illustrated in Figure 2.

Most of the tanks in the site-wide system and all the tanks concerned with in this assessment have rigid-type pipe-to-tank connections. These connections provide little to no flexibility and greatly increase the probability of pipe-to-tank connection failure. There are two typical configurations, the straight pipe configuration exits directly downward through the foundation pad, but the other configuration has the exit located in the sidewall of the tank near the ground. A large pipe, with an angled elbow, connects to this exit and drops directly into the ground as shown in Figure 3. The pipe connection to the water tank is hereafter referred to as a nozzle to avoid confusion with the water distribution piping.

The water level in all tanks is controlled through altitude valves. These valves, along with pressure sensors are monitored using SCADA software. The tanks have cathodic protection systems to mitigate corrosion and wear. In addition, a yearly examination is performed in order to assess the exterior condition of the tanks and their appurtenances.

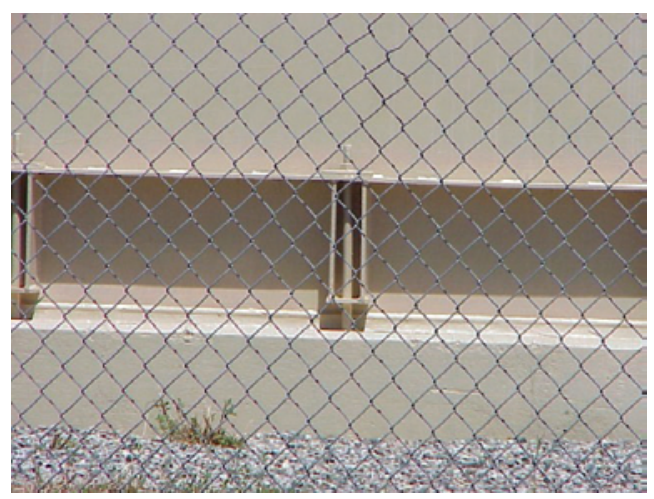

Anchored Tank

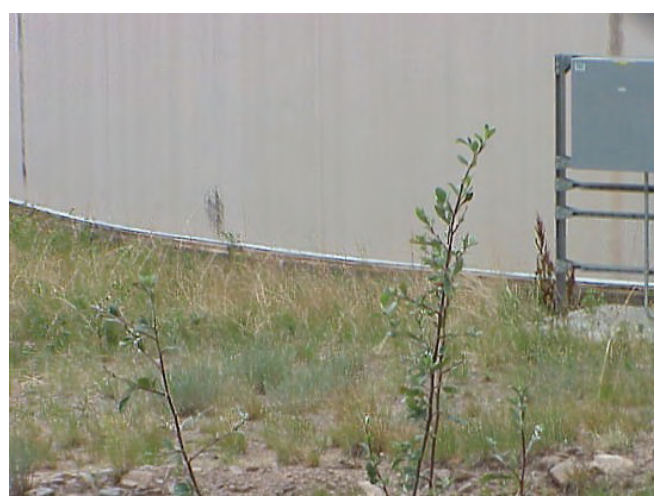

Unanchored Tank

Figure 2. Anchored and unanchored tank base details, (note anchor bolts, bolt chairs, and stiffeners). 


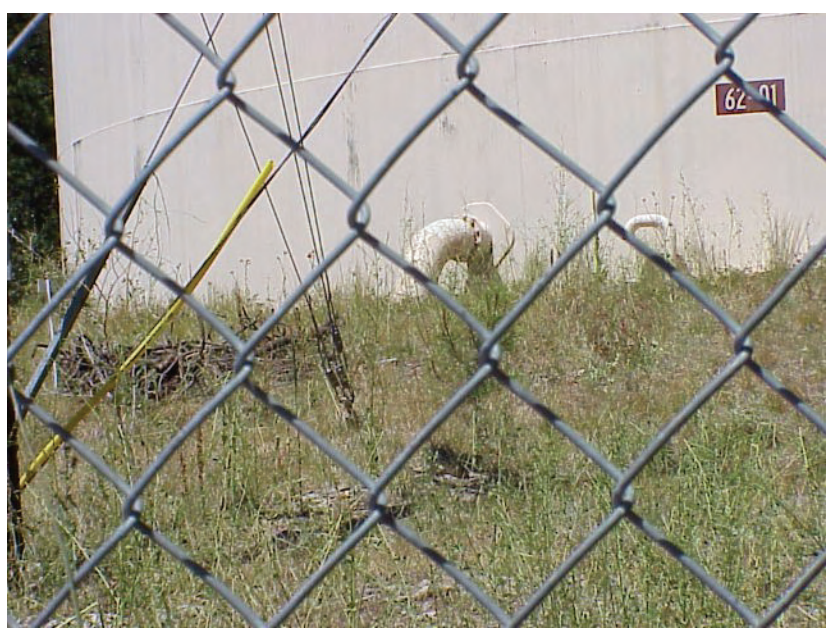

Figure 3. External rigid piping connection (nozzle).

The piping that makes up the actual distribution part of the system considered in this assessment consists of cast iron, concrete cylinder (CCP), copper, ductile iron, galvanized steel, polyvinyl chloride (PVC), steel, and asbestos cement. Cast-iron piping is the dominant material type. Piping diameters range from less than one inch on service lines to approximately 16 inches on main lines, with the majority of distribution pipes having diameters of 8 inches to 12 inches. Approximately 14 miles of piping are included in this assessment.

The piping system has a number of different types of valves. These include isolation valves, backflow prevention valves, and pressure-reducing valves.

Isolation valves are the only valves explicitly considered in this assessment. Most LANL isolation valves are usually left open; however, some are closed to keep water from areas that might freeze. Isolation valves are typically located in valve box housings situated in the ground. These housings have a cap that has been tack-welded on top to prevent tampering. The valves can be closed manually by means of a "T" bar.

\subsection{Facility Descriptions}

Although the five facilities concerned with in this assessment are all part of the lab-wide water-distribution system, it is possible to isolate three facilities with their own storage tank and pipe system. These water-distribution systems are considered independent of each other with completely separate configurations. The remaining two facilities, RLWTF and WCRRF, use a common water distribution system.

The piping lengths reported in the facility descriptions correspond to the minimum lengths required for dedicated supply to CMR, WETF, RLWTF, WCRRF, and TWISP. These lengths are based on existing piping layouts and valve locations.

\subsubsection{CMR Water-Distribution System}

The Chemical and Metallurgy Research facility, CMR (TA-3-29), first began operations in 1952 and since then has been actively working with the chemistry and metallurgy of 
uranium and plutonium. The building is one of the largest at the lab, with an area of 550,000 square feet distributed among seven interconnected wings.

The CMR's water supply is provided by the storage tank located at TA-62-1, shown in Figure 4. This tank holds potable water not dedicated solely for the use of fire protection. The tank supplies domestic water to over 120 separate buildings within TA-3 and other buildings found elsewhere. The tank is unanchored and made of welded steel. The tank connects to its pipe system using the nozzle connection described previously.

CMR is also supplied by water tank, TA-69-7, which has a capacity of 4 Million Gallons. Due to its larger size, Tank TA-69-7 has a larger probability of failure (discussed in Section 4.1.2) than tank TA-62-1. Thus, water supplied from tank TA-69-7 is conservatively omitted from the current assessment.

Water-distribution piping supplying CMR is made of cast iron, ductile iron, galvanized steel, PVC, and copper as shown in Table 2. Up to 48 isolation valves may need to be closed to dedicate the water distribution system to CMR and remove leaking branch lines.

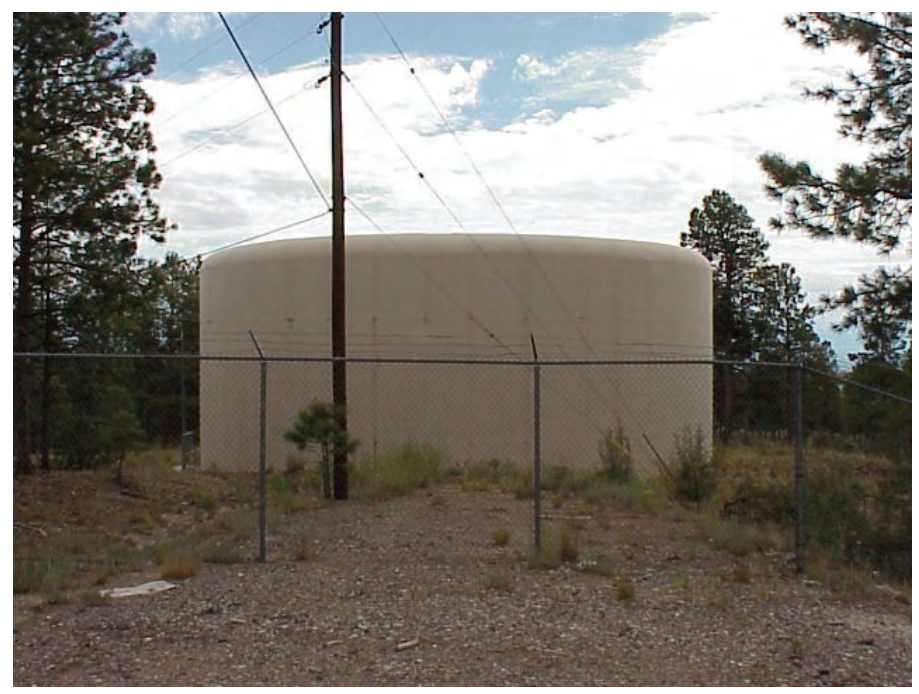

Capacity: 1.5 million gallons Height: $35 \mathrm{ft}$ Width: $85 \mathrm{ft}$ Height-to-width ratio: 0.41

Figure 4. Water tank TA-62-1.

Table 2. CMR Distribution System Piping

\begin{tabular}{|c|c|c|}
\hline Material & Diameter (in.) & Length (ft) \\
\hline Cast Iron & $<12$ & 14,627 \\
\hline Galvanized Steel & $<12$ & 788 \\
\hline PVC & $<12$ & 423 \\
\hline Copper & $<12$ & 170 \\
\hline \multicolumn{2}{|c|}{} & 16,008 \\
\hline
\end{tabular}




\subsubsection{WETF Water-Distribution System}

The Weapons Engineering Tritium Facility, WETF (TA-16), is a one-story; 5,000 square foot building that has been in operation since 1989. The primary functions of this facility are to repackage, recycle, analyze, and mix tritium gas products.

WETF is supplied by two identical tanks located in the same area within TA-16 as shown in Figure 5. These tanks are used both for domestic and fire-protection supply for over 75 buildings within TA-16 as well as buildings in other Technical Areas. Both tanks are made of welded steel and are unanchored. The tanks have a common source and discharge piping configuration. It is not known if the loss of one tank would drain the second tank and both independent and coupled tank cases are considered. The tanks connect to the pipe system using a rigid connection that is routed directly through the concrete foundation into the ground.

The WETF pipe system consists of four types of pipe material: cast iron, steel, ductile iron, and copper as summarized in Table 3 . Up to 30 isolation valves may need to be closed to dedicate the water distribution system to WETF and remove leaking branch lines.

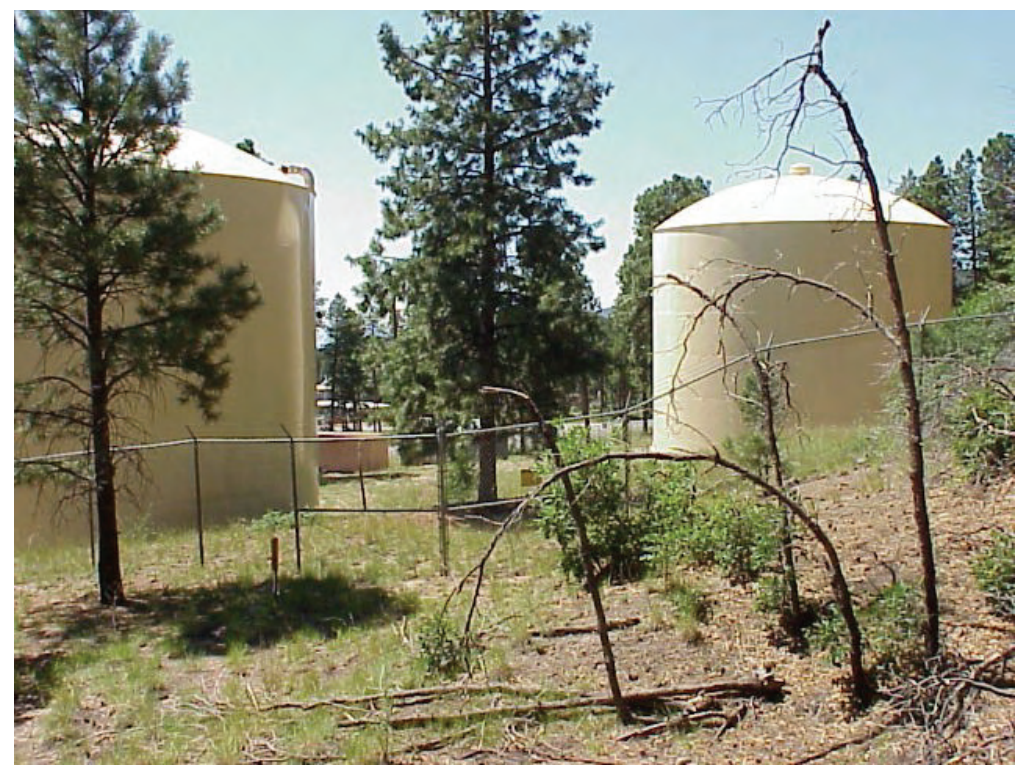

Two identical tanks Capacity: 1 million gallons each Height: $48 \mathrm{ft}$ Width: $60 \mathrm{ft}$ Height-to-width ratio: 0.81

Figure 5. Water Tank TA-16-171 and TA-16-247.

Table 3. WETF Water Distribution System Piping

\begin{tabular}{|l|c|c|}
\hline Material & Diameter (in.) & Length (ft) \\
\hline Cast Iron & $<12$ & 8,399 \\
\hline Steel & $<12$ & 2,980 \\
\hline Ductile Iron & $<12$ & 476 \\
\hline Copper & $<12$ & 70 \\
\hline \multicolumn{2}{|l|}{} & 11,925 \\
\hline
\end{tabular}




\subsubsection{RLWTF and WCRRF Water-Distribution System}

The Radioactive Liquid Waste Treatment Facility, RLWTF (TA-50-1) treats the radioactive liquid waste generated from other various facilities within the lab. Solid waste is repackaged in the Waste Characterization, Reduction and Repackaging Facility, WCRRF (TA-50-69).

The first upstream water tank supplying RLWTF and WCRRF is identified as TA-64-3, shown in Figure 6. Within TA-50 alone TA-64-3 tank supplies domestic water to over 30 buildings not including RLWTF and WCRRF. This tank also supplies other buildings outside TA-50. The tank is anchored to the foundation, as shown in Figure 2. The water distribution piping associated with the RLWTF and WCRRF is summarized in Table 4 and has a total length of 12,458 feet. Up to 35 isolation valves may need to be closed to dedicate the water distribution system to RLWTF/WCRRF and remove leaking branch lines.

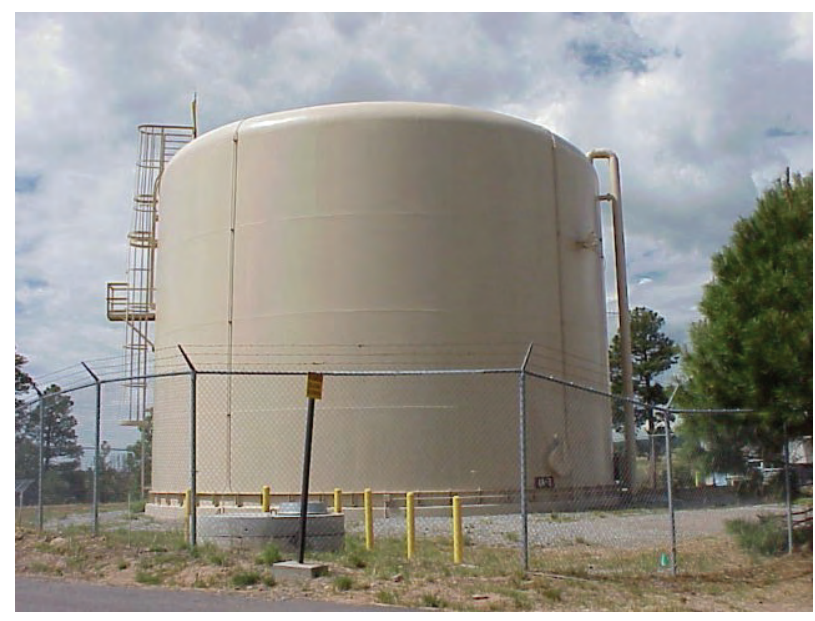

Capacity: 500,000 gallons

Height: $35 \mathrm{ft}$

Width: $49 \mathrm{ft}$

Height-to-width ratio: 0.71

Figure 6. Water tank TA-64-3.

Table 4. RLWTF and WCRRF Distribution System Piping

\begin{tabular}{|c|c|c|}
\hline Material & Diameter (in.) & Length (ft) \\
\hline Cast Iron & $<12$ & 13,315 \\
\hline Transite & $<12$ & 600 \\
\hline Galvanized Steel & $<12$ & 110 \\
\hline Ductile Iron & $<12$ & 1,635 \\
\hline \multicolumn{2}{|c|}{} & 15,660 \\
\hline
\end{tabular}




\subsubsection{TWISP Water-Distribution System}

The TWISP (TA-54-Area G) facility retrieves, identifies, and stores drums and reinforced boxes containing waste.

TWISP is supplied water by a tank TA-54-1006 shown in Figure 7. This tank has a direct line to Pajarito Wells No. 2, 4, and 5. This tank is made of welded steel and is unanchored. In normal operations, the tank provides domestic water to more than 30 other buildings within TA-54 and to buildings in other areas. A common source and discharge design have been implemented for the tank. The pipe-to-tank connection is rigid and is routed directly through the bottom of the foundation pad.

The pipe system is made up primarily of PVC as shown in Table 5. Additional materials involved with this system are CCP, ductile iron, copper, and galvanized steel. Up to 17 isolation valves may need to be closed to dedicate the water distribution system to TWISP and remove leaking branch lines.

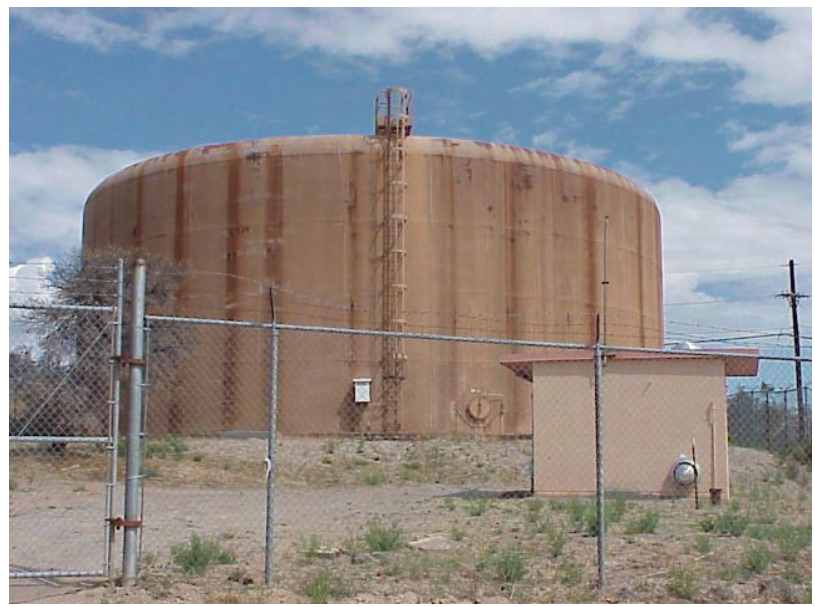

Capacity: 1.5 million gallons

Height: $35 \mathrm{ft}$

Width: $85 \mathrm{ft}$

Height-to-width ratio 0.41

Figure 7. Water tank TA-54-1006.

Table 5. TWISP Water Distribution System Piping

\begin{tabular}{|c|c|c|}
\hline Material & Diameter (in.) & Length (ft) \\
\hline PVC & 16 & 5,156 \\
\hline CCP & 18 & 131 \\
\hline PVC & $<12$ & 17,662 \\
\hline Ductile Iron & $<12$ & 1,103 \\
\hline Galvanized Steel & $<12$ & 341 \\
\hline Copper & $<12$ & 52 \\
\hline \multicolumn{2}{|c|}{} \\
\hline
\end{tabular}




\section{Analysis Methodology}

The methodology used in this assessment follows the American Lifelines Alliance (ALA) seismic fragility formulations for water systems that considers the individual probability

of failure because of

- Pipe Break

○ Wave propagation

- Permanent ground displacement

- Fault displacement

- Tank Failure

- Base weld failure

○ Wall buckling

- Inlet-outlet pipe damage

- Permanent ground deformation

System-level failure frequencies are convolved with the facility seismic hazard to determine the failure frequency. Failure frequencies are compared to the DOE-STD-1020 performance goals.

\subsection{Component Fragilities}

\subsubsection{Pipe Break}

The ALA probabilistic pipe break models consider pipe damage caused by three major contributors. The first contributor is wave propagation. Wave propagation damage is damage directly related to the ground shaking and includes the wave passage effects considered in the American Society of Civil Engineers (ASCE) 4. The second contributing factor is permanent ground deformation. Permanent ground deformation damage is primarily attributed to liquefaction but can include differential settlement, landslides, etc. The third factor included in the model is fault offset. Fault offset damage imposes the fault displacements on short sections of pipe.

\subsubsection{Wave Propagation and Ground Deformation}

Both wave propagation and ground deformation damage are based on empirical pipe repair ratio $(\mathrm{RR})$ vulnerability relationships that include factors to account for different materials, joints, soils, and diameters. The RRs for wave propagation and permanent ground deformation can be determined using the following formulas.

Wave Propagation:

$$
\begin{aligned}
& \mathrm{RR}=\mathrm{K} 1 \times 0.00187 \mathrm{PGV} \\
& \sigma_{\operatorname{lnK}}=1.15
\end{aligned}
$$

Permanent Ground Deformation:

$$
\begin{aligned}
& \mathrm{RR}=\mathrm{K} 2 \times 1.06 \mathrm{PGD}_{\mathrm{L}}^{0.319} \\
& \sigma_{\operatorname{lnK}}=0.74
\end{aligned}
$$

where: RR = mean number of repairs per 1,000 feet of pipe,

$\sigma_{\operatorname{lnK}}=$ logarithmic standard deviation, 
PGV = Peak Ground Velocity, inches/second,

$\mathrm{PGD}_{\mathrm{L}}=$ Permanent Ground Deformation, inches,

$\mathrm{K} 1$ and $\mathrm{K} 2$ are modifiers defined in Tables 6 and 7 .

Table 6. Pipe Modification Factors for Wave Propagation

\begin{tabular}{|l|l|l|l|l|}
\hline Pipe Material & Joint Type & Soils & Diam. & K1 \\
\hline Cast iron & Cement & All & $\leq 12^{\prime \prime}$ & 1.0 \\
\hline Cast iron & Cement & Corrosive & $\leq 12^{\prime \prime}$ & 1.4 \\
\hline Cast iron & Cement & Noncorrosive & $\leq 12^{\prime \prime}$ & 0.7 \\
\hline Cast iron & Rubber gasket & All & $\leq 12^{\prime \prime}$ & 0.8 \\
\hline Welded steel & Lap-Arc welded & All & $\leq 12^{\prime \prime}$ & 0.6 \\
\hline Welded steel & Lap-Arc welded & Corrosive & $\leq 12^{\prime \prime}$ & 0.9 \\
\hline Welded steel & Lap-Arc welded & Noncorrosive & $\leq 12^{\prime \prime}$ & 0.3 \\
\hline Welded steel & Lap-Arc welded & All & $\geq 16^{\prime \prime}$ & 0.15 \\
\hline Welded steel & Rubber gasket & All & $\leq 12^{\prime \prime}$ & 0.7 \\
\hline Welded steel & Screwed & All & $\leq 12^{\prime \prime}$ & 1.3 \\
\hline Welded steel & Riveted & All & $\leq 12^{\prime \prime}$ & 1.3 \\
\hline Asbestos cement & Rubber gasket & All & $\leq 12^{\prime \prime}$ & 0.5 \\
\hline Asbestos cement & Cement & All & $\leq 12^{\prime \prime}$ & 1.0 \\
\hline Concrete w/Stl Cyl. & Lap-Arc Welded & All & $\geq 16^{\prime \prime}$ & 0.7 \\
\hline Concrete w/Stl Cyl. & Cement & All & $\geq 16^{\prime \prime}$ & 1.0 \\
\hline Concrete w/Stl Cyl. & Rubber Gasket & All & $\geq 16^{\prime \prime}$ & 0.8 \\
\hline PVC & Rubber gasket & All & $\leq 12^{\prime \prime}$ & 0.5 \\
\hline Ductile iron & Rubber gasket & All & $\leq 12^{\prime \prime}$ & 0.5 \\
\hline
\end{tabular}

Steel cylinder

Table 7. Pipe Modification Factors for Permanent Ground Displacement

\begin{tabular}{|l|l|l|}
\hline Pipe Material & Joint Type & K2 \\
\hline Cast iron & Cement & 1.0 \\
\hline Cast iron & Rubber gasket & 0.8 \\
\hline Cast iron & Mechanical restraint & 0.7 \\
\hline Welded steel & $\begin{array}{l}\text { Arc welded, lap welds (large } \\
\text { diameter, noncorrosive) }\end{array}$ & 0.15 \\
\hline Welded steel & Rubber gasket & 0.7 \\
\hline Asbestos cement & Rubber gasket & 0.8 \\
\hline Asbestos cement & Cement & 1.0 \\
\hline Concrete w/Stl Cyl. & Welded & 0.6 \\
\hline Concrete w/Stl Cyl. & Cement & 1.0 \\
\hline Concrete w/Stl Cyl. & Rubber gasket & 0.7 \\
\hline PVC & Rubber gasket & 0.8 \\
\hline Ductile iron & Rubber gasket & 0.5 \\
\hline
\end{tabular}


The RR is based on utility repair records following the 1995 Kobe, 1994 Northridge, 1989 Loma Prieta, and 1971 San Fernando earthquakes. It is important to note that the utility crews were focused on returning the water system to service and that some records are incomplete. Thus, there were repairs made that are not reflected in the empirical database. On the conservative side, damage ranged from completely severed lines to functional lines that leaked. Additionally, some repairs were repeated and recorded multiple times, at locations where the ground continued to creep following the earthquake. It is our judgment that these effects are offsetting and that the RR represents the best estimate of pipe failure.

ALA uses a Poisson probability distribution to calculate the probability of an individual pipe link, remaining in service with zero repairs (not breaking) as

$$
\mathrm{P}_{\text {Pipe InService }}=\mathrm{e}^{-\lambda \mathrm{L}} \text {, }
$$

where, $\lambda=$ the larger of wave propagation or permanent ground deformation $R R$, and

$\mathrm{L}=$ length of pipe, in 1,000 feet.

The probability of failure for an entire run of pipes is

$$
\mathrm{P}_{\mathrm{f}}=\mathrm{P}_{\text {Pipeline Out of Service }}=1-\left.\prod \mathrm{P}_{\text {Pipe In Service }}\right|_{\mathrm{i}}
$$

\subsubsection{Fault Offset}

The ALA probability of failure because of fault crossing is represented by the following relationships, which are shown in Figure 8.

Continuous pipeline (e.g., welded steel)

$$
P_{f}=0.70 \times \frac{P G D_{f}}{60} \leq 0.95
$$

Segmented pipeline

$$
\mathrm{PGD}_{\mathrm{f}}=0^{\prime \prime} \quad \mathrm{P}_{\mathrm{f}}=0
$$

(e.g., cast iron with cemented joints)

$$
\begin{aligned}
1 " \leq \mathrm{PGD}_{\mathrm{f}} \leq 12^{\prime \prime} & \mathrm{P}_{\mathrm{f}}=0.50 \\
13^{\prime \prime} \leq \mathrm{PGD}_{\mathrm{f}} \leq 24^{\prime \prime} & \mathrm{P}_{\mathrm{f}}=0.80 \\
24^{\prime \prime} \leq \mathrm{PGD}_{\mathrm{f}} & \mathrm{P}_{\mathrm{f}}=0.95
\end{aligned}
$$

Where: $\mathrm{PGD}_{\mathrm{f}}$ is the permanent ground deformation of the fault.

\subsubsection{Tank Failure}

The ALA probabilistic tank failure model considers the following tank failure modes that are applicable to LANL water tanks:

(1) Base Weld Failure: Most LANL tanks have a circular bottom plate and cylindrical walls. The weld at the wall-bottom junction must resist bending caused by internal pressure in addition to uplift and shear forces from seismic loads. Overstressing this weld results in a rupture that can release the tank's contents. 


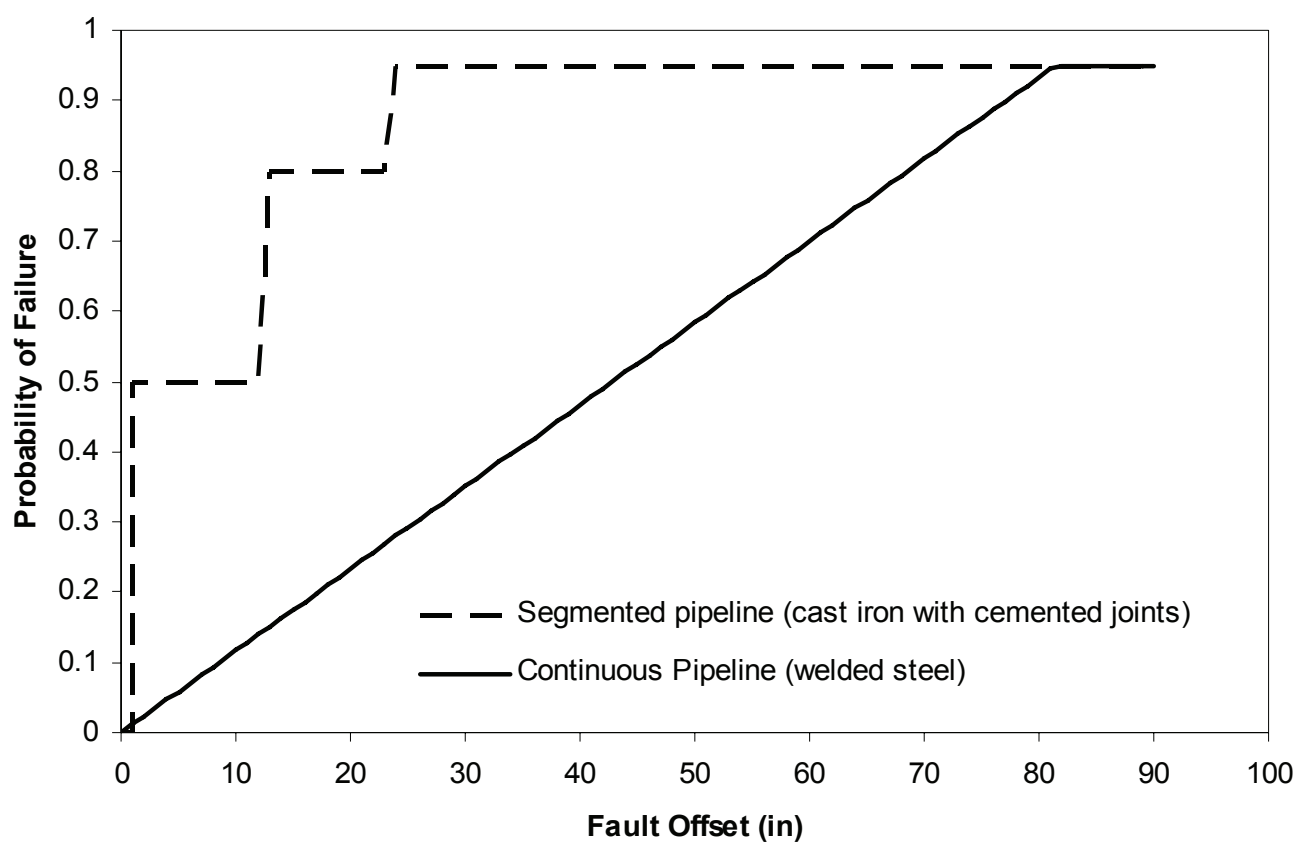

Figure 8. Probability of pipe failure caused by a fault offset.

(2)Inlet-Outlet Pipe Fracture: Fracture of piping rigidly connected to the tank is a common mode of failure that is typically caused by vertical tank displacements caused by uplift, buckling, or foundation failure. Pipe fracture can also be caused by tank sliding. The piping connections to LANL tanks that were considered in the scope of this evaluation are rigid with little flexibility to accommodate seismic deformations.

(3) Buckling: During a seismic event, portions of the tank wall are susceptible to buckling. The "elephant foot" buckling mode is common for water tanks and is considered in this assessment. During elephant foot buckling, portions of the tank wall experience very high strains and may rupture, releasing the tank's contents. Small amounts of buckling, which do not rupture the tank wall, are omitted from this assessment. Inlet-outlet pipes are called nozzles in this assessment to avoid confusion with water-distribution piping.

(4) Permanent Ground Deformation: Damage resulting from PGD is most commonly attributed to liquefaction; however, other causes associated with seismic events are also likely, including, but not limited to, landslides and differential settlement.

Because this assessment is focused on the water supply for fire suppression, damage states that do not challenge functionality have been omitted.

The ALA representative fragility curves are used to assess the tank failure frequency that is summarized in Table 8. These curves are based on average results of analytical calculations for various classes of water tanks supplemented by engineering judgment. The ALA document warns that these curves should only be considered representative of 
fragilities for specific tanks and should always be adjusted for tank-specific conditions. In consideration of this caution, the ALA representative fragility curves are interpreted to represent the average behavior of the six tank populations considered in this assessment.

Table 8. ALA Representative Tank Fragility Curves

\begin{tabular}{|c|c|c|c|c|}
\hline Class & Damage State & Parameter & Median & Beta \\
\hline \multicolumn{5}{|c|}{ Unanchored Steel Tank 100,000 to $2,000,000$ gallons (CMR, TWISP, WETF x 2) } \\
\hline & Weld failure at base-loss of contents & Sa@8hz & $3.0 \mathrm{~g}$ & 0.50 \\
\hline & Nozzle Failure-loss of contents & Sa@8 hz & $1.8 \mathrm{~g}$ & 0.50 \\
\hline & Elephant foot buckle-loss of contents & $\mathrm{Sa} @ 8 \mathrm{hz}$ & $1.0 \mathrm{~g}$ & 0.50 \\
\hline & Ground failure & PGD & 36 in. & 0.50 \\
\hline \multicolumn{5}{|c|}{ Anchored Steel Tank 100,000 to 2,000,000 gallons (RLWTF \& WCRRF) } \\
\hline & Weld failure at base- - loss of contents & $\mathrm{Sa} @ 7 \mathrm{hz}$ & $5.7 \mathrm{~g}$ & 0.50 \\
\hline & Nozzle Failure-loss of contents & Sa@7hz & $4.0 \mathrm{~g}$ & 0.50 \\
\hline & Elephant foot buckle-loss of contents & Sa@7hz & $5.5 \mathrm{~g}$ & 0.50 \\
\hline & Ground failure & PGD & 36 in. & 0.50 \\
\hline \multicolumn{5}{|c|}{ Unanchored Steel Tank >2,000,000 gallons (None in this assessment) } \\
\hline & Weld failure at base-loss of contents & Sa@5 hz & $2.1 \mathrm{~g}$ & 0.50 \\
\hline & Nozzle Failure-loss of contents & $\mathrm{Sa} @ 5 \mathrm{hz}$ & $1.4 \mathrm{~g}$ & 0.50 \\
\hline & Elephant foot buckle-loss of contents & Sa@5hz & $0.75 \mathrm{~g}$ & 0.50 \\
\hline & Ground failure & PGD & 36 in. & 0.50 \\
\hline \multicolumn{5}{|c|}{ Anchored Steel Tank >2,000,000 gallons (None in this assessment) } \\
\hline & Weld failure at base-loss of contents & Sa@ 5 hz & $3.6 \mathrm{~g}$ & 0.50 \\
\hline & Nozzle Failure-loss of contents & Sa@5 hz & $3.2 \mathrm{~g}$ & 0.50 \\
\hline & Ground failure & PGD & 36 in. & 0.50 \\
\hline
\end{tabular}

\subsubsection{Component Failure}

Components such as valves, fire hydrants, etc., are typically very robust to ensure operability. These components are assumed to be more rugged compared to the piping that they are connected to. As such, the fragility of these components is judged not to contribute to the system fragilities reported below.

\subsection{System Fragility and Probability of Failure}

System fragilities are developed using the process in Reference 11. For a given ground motion level, the probability of failure of each component is calculated from the component fragility curves. For the water distribution system, failure occurs if either the piping OR any of the tank components fail. Thus, the probability of system failure, given a specific ground motion level, is 


$$
\mathrm{P}_{\mathrm{f} \text { System }}=\mathrm{P}_{\mathrm{fA}}+\left(1-\mathrm{P}_{\mathrm{fA}}\right)\left[\mathrm{P}_{\mathrm{fB}}+\left(1-\mathrm{P}_{\mathrm{fB}}\right)\left\{\mathrm{P}_{\mathrm{fC}}+\left(1-\mathrm{P}_{\mathrm{fC}}\right)\left(\mathrm{P}_{\mathrm{fD}}+\ldots\right)\right\}\right]
$$

where, $\mathrm{P}_{\mathrm{fA}}, \mathrm{P}_{\mathrm{fB}}$, etc., are the probabilities of failure of the water-distribution piping, tankbase weld, tank-piping connection, tank-wall bucking, etc., at the specific ground-motion level.

The system fragility curve is constructed by plotting the system probability of failure for different magnitudes of a common ground motion parameter. The ground-motion parameter may be either PGA, PGV, spectral acceleration, etc.

The annual probability of failure for a system is determined by a convolution of the seismic hazard and system fragility curves $[10,11]$.

$$
\text { Pf }=\int_{0}^{\infty} \mathrm{H}(\mathrm{a})\left(\frac{\mathrm{dP}_{\mathrm{F} / \mathrm{a}}}{\mathrm{da}}\right) \mathrm{da},
$$

where $\mathrm{dPF} / \mathrm{a} / \mathrm{da}$ is the conditional probability density function that describes the probability of failure (PF), given an earthquake in the range da, and $\mathrm{H}(\mathrm{a})$ is the seismic hazard curve.

\subsection{Seismic Input}

\subsubsection{Ground Motion}

Peak ground displacement, velocity, and acceleration are extracted from the current Probabilistic Seismic Hazards Analysis (PSHA) [7] time histories for 500 to 10,000 year return periods and summarized in Table 9.

Table 9. Seismic Hazard for Peak Ground Parameters

\begin{tabular}{|c|c|c|c|c|}
\hline Return Period & $\begin{array}{c}\text { Annual Exceedance } \\
\text { Probability }\end{array}$ & $\begin{array}{c}\text { PGA } \\
\text { (g) }\end{array}$ & $\begin{array}{c}\text { PGV } \\
\text { (ips) }\end{array}$ & $\begin{array}{c}\text { PGD } \\
\text { (in.) }\end{array}$ \\
\hline 100 & $1 \times 10^{-2}$ & 0.04 & 1.14 & 0.73 \\
\hline 500 & $2 \times 10^{-3}$ & 0.16 & 4.33 & 2.76 \\
\hline 1,000 & $1 \times 10^{-3}$ & 0.22 & 7.87 & 3.62 \\
\hline 2,000 & $5 \times 10^{-4}$ & 0.31 & 12.60 & 4.92 \\
\hline 10,000 & $1 \times 10^{-4}$ & 0.60 & 32.28 & 11.81 \\
\hline
\end{tabular}

The PSHA developed seismic hazards at TA-2, -3, -16, -18, -21, -41, -46, and -55. This assessment includes systems, structures, and components (SSCs) in TA-3, -16, -50, and 54. The seismic hazard at TA-55 is used for TA-50 because the two facilities are adjacent to each other. Sites TA-46 and TA-54 are close to each other and both are located on top of the same mesa. Thus, the seismic hazard at TA-54 is represented by the seismic hazard at TA-46.

The peak ground acceleration at 100 years is measured from the TA-3, $-16,-46$, and -55 hazard curves. At the 100-year return period, the peak ground velocity and displacement 
are the 500-year velocity/acceleration (V/A) and displacement/acceleration (D/A) ratios times the 100-year peak ground acceleration.

The PSHA provides surface motions that take LANL-specific site amplification into account. Thus, the International Building Code (IBC) [12] surface motion amplification factors need not be applied to the PSHA results. Interpolating the data in Table 10 for a 2,500-year "Maximum Credible Earthquake" (MCE) specified by IBC yields the peak ground acceleration, velocity, and displacements in Table 11. The IBC design ground motion is based on two-thirds of the MCE that is also shown in the table.

The LANL Engineering Standards Manual (ESM) [13] follows the IBC procedure for determining surface ground motions for LANL and specifies $\mathrm{S}_{\mathrm{DS}}=0.54 \mathrm{~g}$ for PC-1 and PC-2 structures. Using the IBC spectral amplification factor of $2.5, \mathrm{~S}_{\mathrm{DS}}=0.54 \mathrm{~g}$ corresponds to a 0.216 g PGA. Thus, the IBC design ground motion for PC-1 and PC-2 $\mathrm{SSC}$, is consistent with the LANL PSHA.

Table 10. IBC Ground Motion Parameters

\begin{tabular}{|c|c|}
\hline $\begin{array}{c}\text { 2,500 years } \\
\text { Maximum Credible Earthquake (MCE) }\end{array}$ & IBC Design Ground Motion \\
\hline $\mathrm{PGA}=0.35 \mathrm{~g}$ & $\mathrm{PGA}=0.23 \mathrm{~g}$ \\
\hline $\mathrm{PGV}=15 \mathrm{ips}$ & $\mathrm{PGV}=10 \mathrm{ips}$ \\
\hline $\mathrm{PGD}=5.9 \mathrm{in}$. & $\mathrm{PGD}=3.9 \mathrm{in}$. \\
\hline
\end{tabular}

inches per second

Table 11. Mean Probabilistic Fault Displacements (in.) $[8,9]$

\begin{tabular}{|c|c|c|c|c|c|c|c|c|}
\hline Return Period & \multicolumn{2}{|c|}{500} & \multicolumn{2}{c|}{1,000} & \multicolumn{2}{c|}{2,000} & \multicolumn{2}{c|}{10,000} \\
\hline APE & \multicolumn{2}{|c|}{$2 \times \mathbf{1 0}^{-3}$} & \multicolumn{2}{c|}{$1 \times \mathbf{1 0}^{-3}$} & \multicolumn{2}{c|}{$5 \times \mathbf{1 0}^{-4}$} & \multicolumn{2}{c|}{$1 \times \mathbf{1 0}^{-4}$} \\
\hline & TA-3 & TA-16 & TA-3 & TA-16 & TA-3 & TA-16 & TA-3 & TA-16 \\
\hline $\begin{array}{c}\text { Distributed Faulting } \\
\text { Case 1a }\end{array}$ & $<<0.1$ & $<<0.1$ & $<<0.1$ & $<<0.1$ & $<<0.1$ & $<<0.1$ & $\approx 0.1$ & $<0.1$ \\
\hline Case 1b & $<<0.1$ & $<<0.1$ & $<<0.1$ & $<<0.1$ & $<<0.1$ & $<<0.1$ & $<<0.1$ & $<<0.1$ \\
\hline Case 1c & $<<0.1$ & $<<0.1$ & $<<0.1$ & $<<0.1$ & $<<0.1$ & $<<0.1$ & $<<0.1$ & $<<0.1$ \\
\hline $\begin{array}{c}\text { Principal Faulting } \\
\text { Case 2 }\end{array}$ & $<<0.1$ & $<<0.1$ & $<<0.1$ & $<<0.1$ & $<<0.1$ & $<0.1$ & 0.67 & 21 \\
\hline
\end{tabular}


Note that the peak ground parameters are not modified by the IBC importance factor, I for PC-2 SSC. IBC has one earthquake, which is two-thirds the maximum considered earthquake or two-thirds of an earthquake with a 2,500-year mean return period. The importance factor is included in the base shear term $(\mathrm{R} / \mathrm{I})$, which reflects that buildings with a high importance factor, such as fire stations and hospitals, have less damage and are available for immediate occupancy. The base shear term $(\mathrm{R} / \mathrm{I})$ is conservatively assumed to be unity in this assessment.

\subsubsection{Response Spectra}

The PSHA generates site-specific response spectra at each technical area. However, there is typically a small variation in spectral acceleration between TA-3, -16, -46, and -55, as shown in Figure 9. This variation is not significant for this assessment. The spectral accelerations at the four sites are averaged together to form a composite seismic hazard curve, shown in Figure 10, which is used for the different technical areas in this assessment.

\subsubsection{Permanent Ground Deformation}

The database used to develop permanent ground deformation is predominately based on liquefaction events. Liquefaction occurs in saturated soils. Because liquefaction only occurs in saturated soil, its effects are most commonly observed in low-lying areas near bodies of water such as rivers, lakes, bays, and oceans [14, 15]. The facilities considered in this assessment are located on mesa tops with a typical depth to the water table of over 900 feet. Liquefaction events are very improbable for these soil conditions and are not considered further for PC-2 SSC.

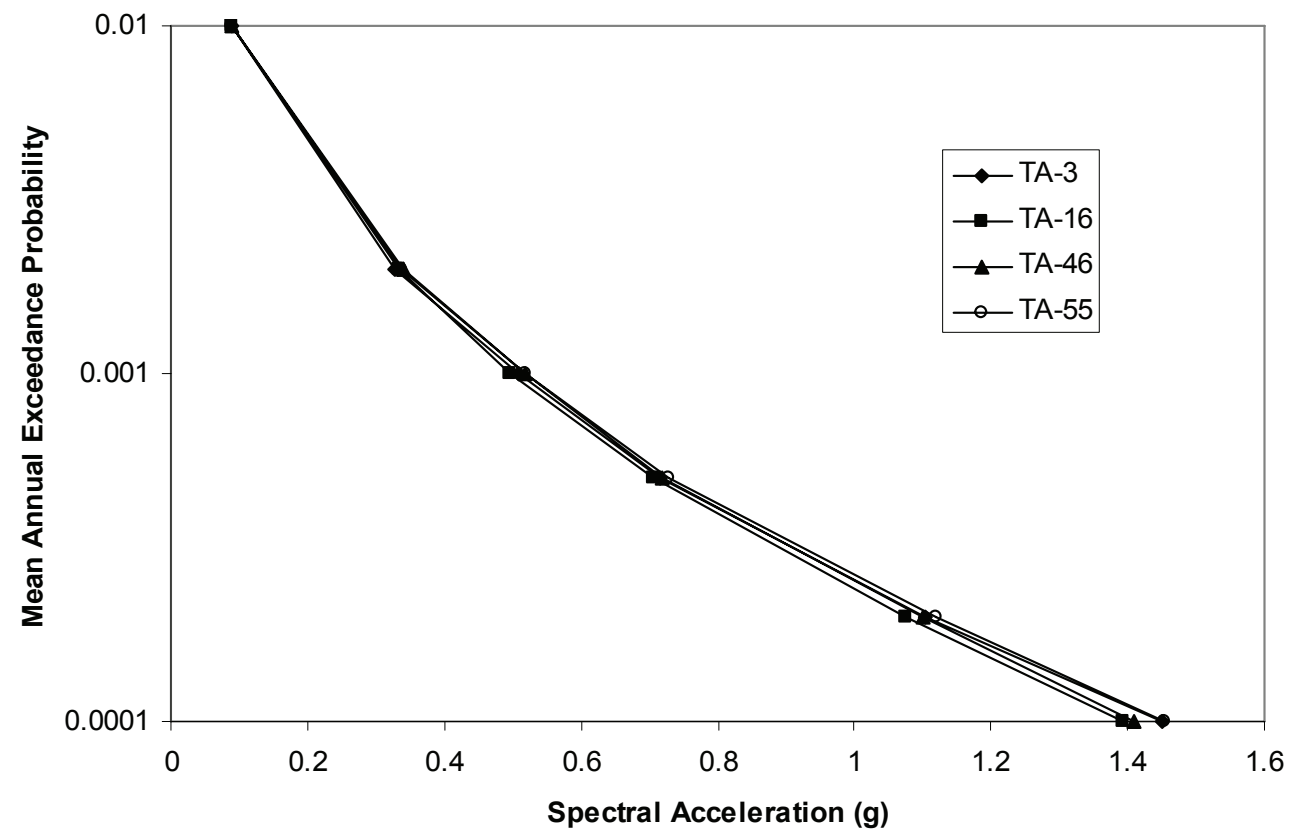

Figure 9. Seismic hazard curves for 0.2-second spectral accelerations at different TAs. 


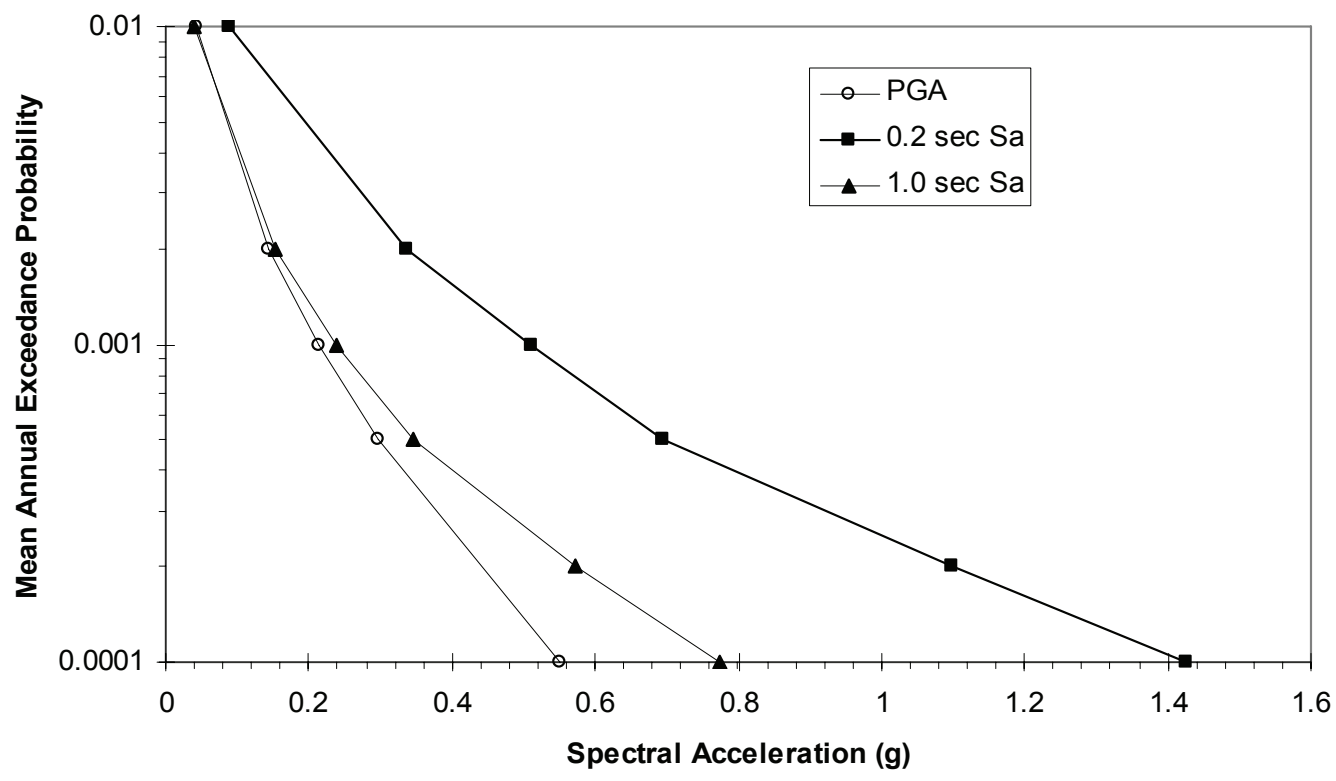

Figure 10. Seismic hazard curve.

Also included in the database are landslides and differential settlement. Landslides typically have large displacements ( $>>10$ inches) over distances ranging from 100 to $1,000+$ feet. Reference 16 parametrically evaluated slope stability for the building in TA-3 near the edge of a mesa subject to PC-2 seismic loading and concluded that there are large factors of safety for the range of tuff properties expected across LANL. Presuming that the slope profiles are representative of slope profiles adjacent to water lines, then the factor of safety for slope stability (landslides) is adequate for PC-2 loadings. Thus, failure caused by peak ground displacement is not considered further for PC-2 SSC.

\subsubsection{Fault Offset}

Probabilistic fault displacements are summarized in Table 11 for TA-3 and TA-16, which are close to portions of the Rendija Canyon and Pajarito fault $[8,9]$. Cases 1a, 1b, and 1c represent distributed faulting. Case 2 is a hypothetical case where a trace of the fault transects the site. The fault displacement hazard curve for TA-16, shown in Figure 11

indicates that the probability of fault displacement is negligible for return periods less than about 3,500 years (annual probability exceedance $[\mathrm{APE}]=2.8 \times 10^{-4}$ ). Thus, failure caused by fault offset is not considered further for PC-2 SSC. 


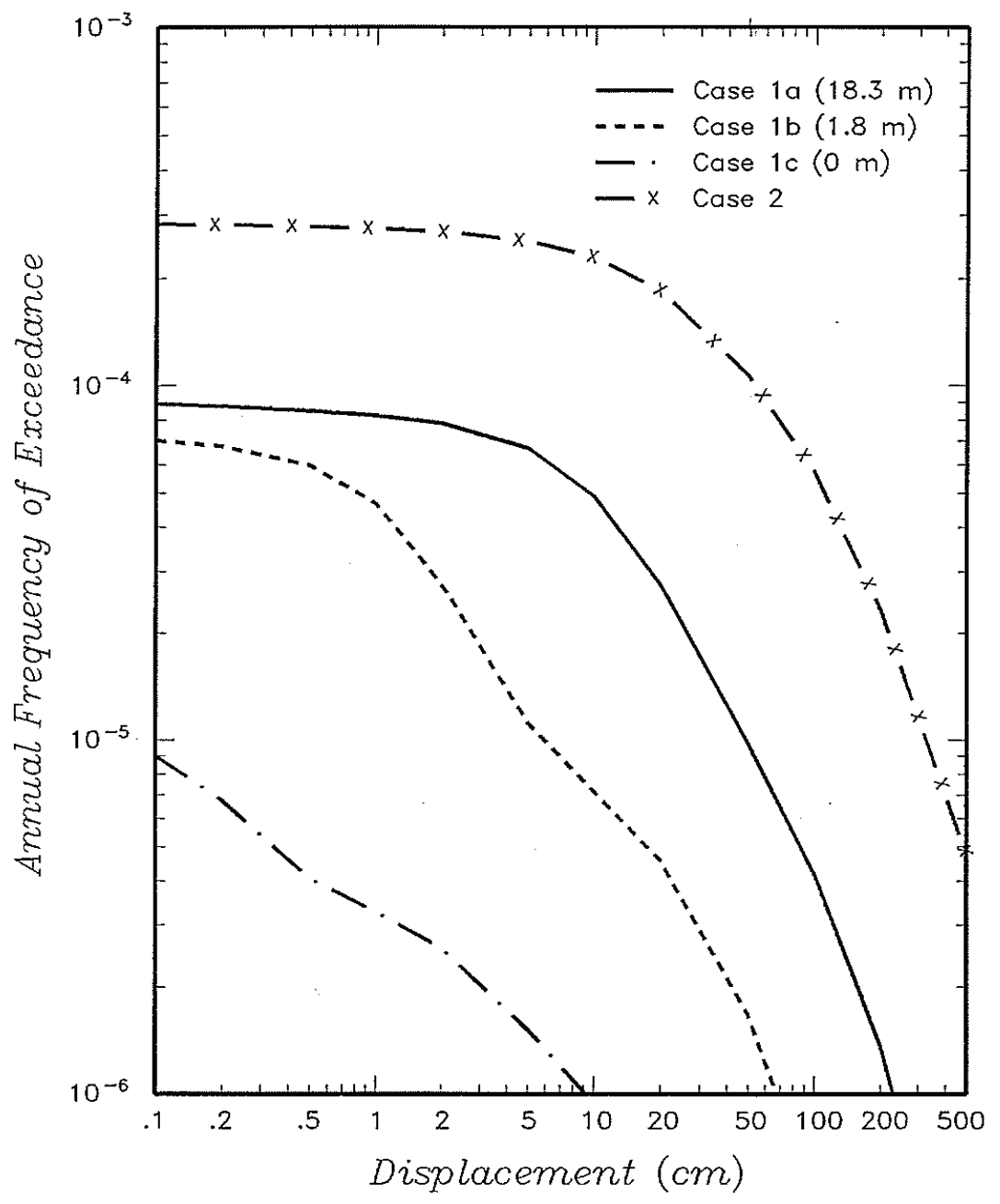

Figure 11. TA-16 probabilistic fault displacement [9].

\subsubsection{Ground Motion Parameter}

The peak ground velocity is chosen as the common ground motion parameter. The 0.2 second spectral acceleration is converted to PGV by

$$
\mathrm{PGV}=\frac{386.4 \mathrm{in} / \mathrm{sec}^{2}}{2 \pi \frac{1}{0.2 \mathrm{sec}}} \frac{\mathrm{Sa}}{\mathrm{g}}=13 \mathrm{ips} \frac{\mathrm{Sa}}{\mathrm{g}},
$$

where $\mathrm{Sa}$ is the 0.2 second spectral acceleration in g's. The shape of the PGV and 0.2 second Sa hazard curves are somewhat different as seen in Figure 12. Using the PGV to estimate the 0.2 second $\mathrm{Sa}$ hazard introduces conservatism for peak ground velocities greater than about 5 ips. 


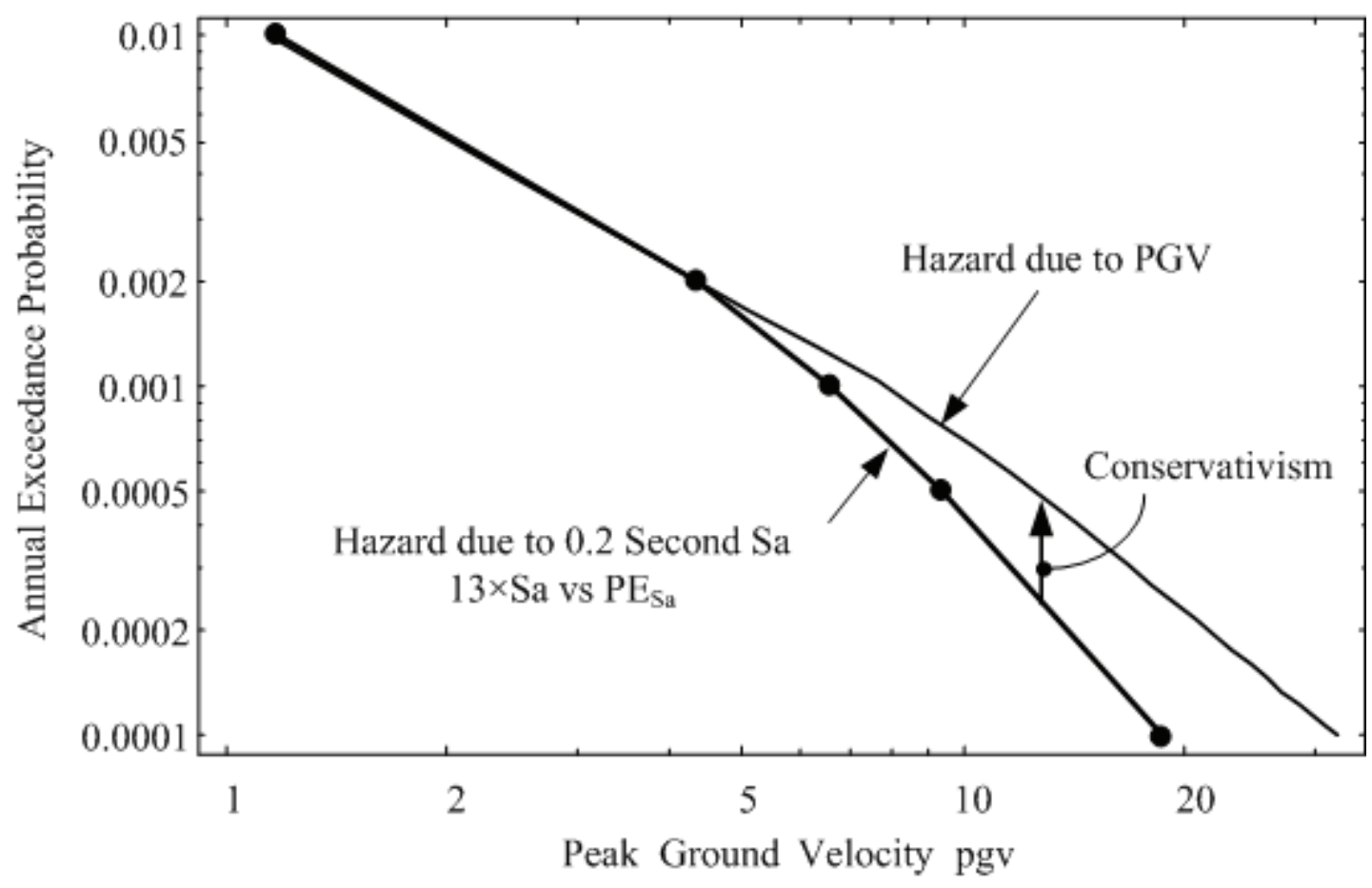

Figure 12. Comparison of hazard curves.

\subsection{Performance Goal for PC-1 and PC-2 SSC}

DOE-STD-1020 defines target performance goals for PC-1, -2, -3, and -4 SSCs, shown in Table 12. For PC-2 SSC, DOE-STD-1020-94 used UBC-94 as the model building code with an importance factor of I $=1.25$ for PC-2 SSC. DOE-1020-2002 uses the IBC-2000 building code with an importance factor of 1.5 for PC-2 SSC. The IBC-2000 seismic requirements are more stringent than the UBC-94 seismic requirements, and the achieved performance of a PC-2 SSC designed to DOE-STD-1020-2002 is better than the target performance goal stated in Table 12 .

DOE-STD-1020 Section 2.4.2 "Evaluation of Existing Facilities" allows the doubling of the seismic hazard for the evaluation of existing SSC.

Table 12. DOE-STD-1020 Performance Goals Annual Probability of Exceeding Acceptable Behavior Limits, PF

\begin{tabular}{|c|c|c|}
\hline & \multicolumn{2}{c|}{ Target Performance Goal } \\
\hline Performance Class & New SSC & Existing SSC \\
\hline PC-1 & $1 \times 10^{-3}$ & $2 \times 10^{-3}$ \\
\hline PC-2 & $5 \times 10^{-4}$ & $1 \times 10^{-3}$ \\
\hline PC-3 & $1 \times 10^{-4}$ & $2 \times 10^{-4}$ \\
\hline PC-4 & $1 \times 10^{-5}$ & $2 \times 10^{-5}$ \\
\hline
\end{tabular}




\section{Component Failure Frequencies}

The failure frequency of individual components is calculated in this section for various levels of seismic input.

\subsection{Pipe Fragilities}

The probability of pipe failure is determined by using:

1) Equation 1 to calculate the repair ratio, RR;

2) Equation 5 to calculate the probability of each individual run of piping remaining in service, $\mathrm{P}_{\text {Pipe In Service; }}$, and

3) Equation 6 to calculate the probability of failure, $P_{f}=P_{\text {Pipe Out Of Service. }}$

The median seismic capacity of is expressed in terms of peak ground velocity, $\mathrm{PGV}_{50}$, which has a $50 \%$ probability of failure, $\mathrm{P}_{\mathrm{f}}=0.50$ and is determined iteratively. $\mathrm{PGV}_{50}$ is summarized in Table 13.

The repair ratio, probability of each individual run of piping remaining in service, and probability of failure for TWISP PGV 50 is shown in Table 14 . The long run $(\approx 3.3$ miles $)$ of small-diameter PVC piping that supplies TWISP is the greatest contributor to risk, followed by the $\approx 1$-mile-long run of large-diameter PVC piping.

Table 13. Summary of $\mathrm{PGV}_{50}$ (ips)

\begin{tabular}{|r|c|c|c|c|c|}
\hline & CMR & RLWTF & TWISP & WCRRF & WETF \\
\hline Median & 28.28 & 44.48 & 24.44 & 133.05 & 42.05 \\
\hline$\sigma_{\text {lnk }}=$ & 1.15 & 1.15 & 1.15 & 1.15 & 1.15 \\
\hline
\end{tabular}

Table 14. TWISP RR, $P_{\text {Pipe In Service, }}$ and $P f$ for $P G V=24.44$ ips

\begin{tabular}{|c|c|c|c|c|c|}
\hline Material & $\begin{array}{c}\text { Diameter } \\
\text { (inch) }\end{array}$ & $\begin{array}{c}\text { Length, } \\
\text { L (ft) }\end{array}$ & K1 & $\begin{array}{c}\text { Repair } \\
\text { Ratio, RR, } \\
\text { per } 1000 \text { ft }\end{array}$ & $\begin{array}{c}\text { Probability of Each } \\
\text { Individual Section } \\
\text { Remaining in Service, } \\
\text { Pipe In Service }\end{array}$ \\
\hline PVC & $>12^{\prime \prime}$ & 5,156 & 1.0 & 0.0457 & 0.7900 \\
\hline $\mathrm{CCP}$ & $>12^{\prime \prime}$ & 131 & 1.0 & 0.0457 & 0.9940 \\
\hline PVC & $<12^{\prime \prime}$ & 17,662 & 0.5 & 0.0229 & 0.6679 \\
\hline Galv. Steel & $<12^{\prime \prime}$ & 341 & 1.3 & 0.0594 & 0.9799 \\
\hline Copper & $<12^{\prime \prime}$ & 52 & 1.0 & 0.0457 & 0.9976 \\
\hline Ductile Iron & $<12^{\prime \prime}$ & 1103 & 0.5 & 0.0229 & 0.9751 \\
\hline \multicolumn{5}{|c|}{$P_{f}=1-\Pi\left(P_{\text {Pipein Service }}\right)=$} & 0.50 \\
\hline
\end{tabular}


Pipe failure fragility curves caused by wave propagation are shown in Figure 13. These curves are constructed by

$$
\mathrm{PGV}=\mathrm{PGV}_{50} \mathrm{e}^{\beta \times \sigma_{\ln \mathrm{K}}},
$$

where $\sigma_{\operatorname{lnK}}$ is the lognormal standard deviation, Equation 2, and

$\beta$ is the number of standard deviations from the median.

The conditional probability of pipe failure caused by wave propagation is extracted from Figure 13 for a peak ground velocity of 10 ips that corresponds to the PC-2 design ground motion and is summarized in Table 15 . The probability of pipe failure is between $11 \%$ for WETF and $22 \%$ for TWISP. CMR has a $0.06-\mathrm{g}$ DBE that corresponds to a peak ground velocity of $0.06 \times(1.14 / 0.04)=1.71 \mathrm{ips}$, where $(1.14 / 0.04)$ is the ratio PGV/PGA from Table 10 for a 100 -year earthquake. From Figure 13, the conditional probability of piping failure for CMR at $0.06 \mathrm{~g} \mathrm{DBE}$ is $1 \%$.

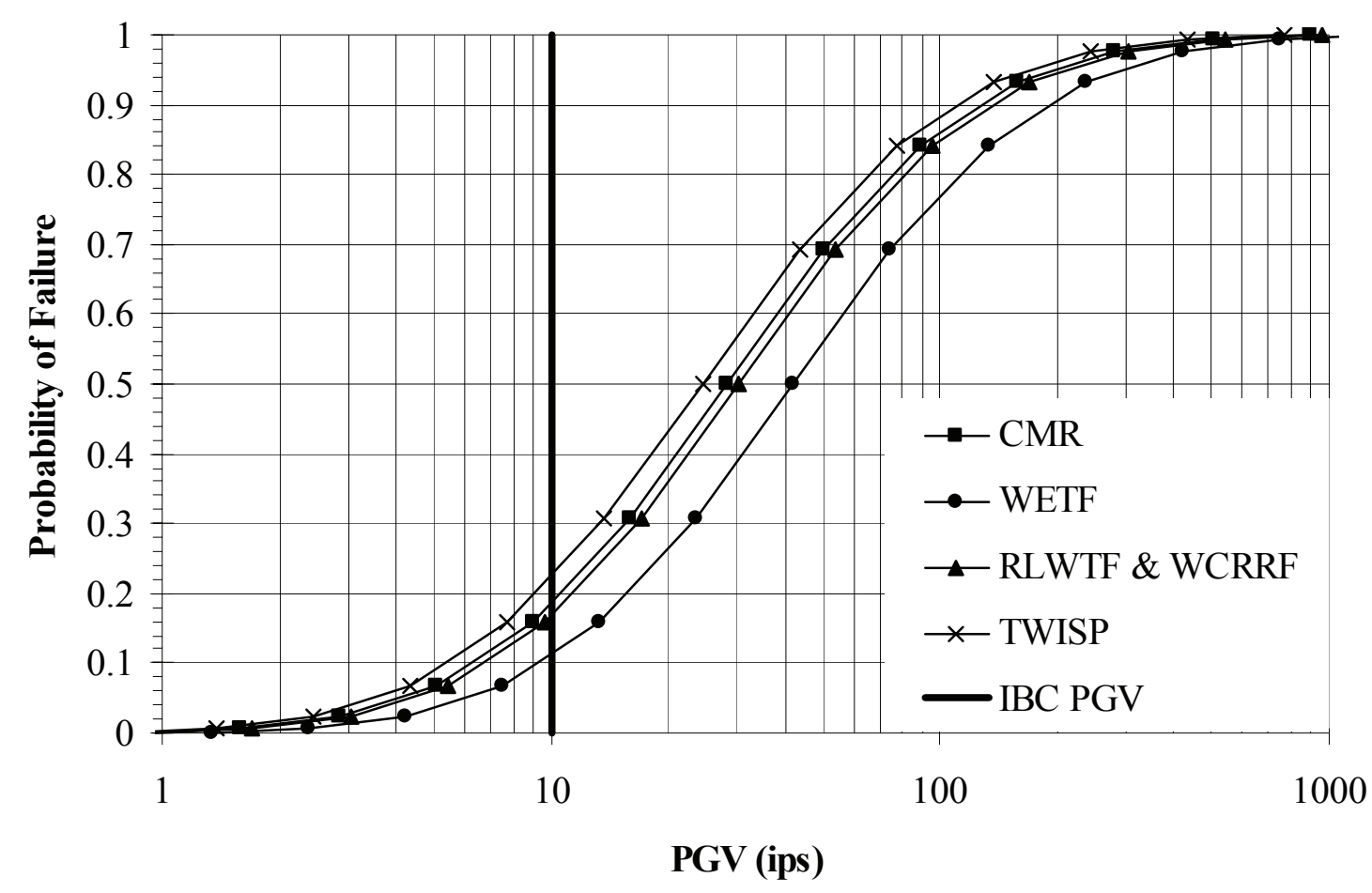

Figure 13. Pipe failure fragility curves due to wave propagation.

Table 15. Conditional Probability of Water Distribution Piping Failure For Acceptance Criteria Earthquake

\begin{tabular}{|l|c|c|c|}
\hline Facility & Acceptance Criteria & PGV (ips) & $\left.\mathrm{P}_{\mathrm{f}}\right|_{\text {DBE }}$ \\
\hline CMR & 0.06 -g DBE & 1.7 & $1 \%$ \\
\hline WETF & PC-2 & 10 & $11 \%$ \\
\hline RLWTF \& WCRRF & PC-2 & 10 & $17 \%$ \\
\hline TWISP & PC-2 & 10 & $22 \%$ \\
\hline
\end{tabular}


The results in Table 16 are based on the assumption that all the existing valves needed to dedicate the water distribution system to a specific facility and remove leaking branch lines are closed. At this time, there is no protocol in emergency response that requires such action.

The water distribution system for a representative technical area, TA-16, which includes the WETF facility, is shown in Figure 14. There are 11,925 feet of piping with the isolation valves closed and 93,127 feet of piping with the isolation valves open. The conditional probability of pipe failure for the PC-2 event is $11 \%$ when the isolation valves are closed and 73\% when the isolation valves are open. Thus, increasing the length of piping by a factor of 8 increased the conditional probability of pipe failure by nearly the same amount.

Table 16. Conditional Probability of Tank Failure for the Acceptance Criteria Earthquake

\begin{tabular}{|l|c|c|c|}
\hline \multicolumn{1}{|c|}{ Facility } & Acceptance Criteria & Sa (g) & $\left.\mathrm{P}_{\mathrm{f}}\right|_{\mathrm{DBE}}$ \\
\hline CMR & $0.06 \mathrm{~g}$ DBE & 0.13 & $<<1 \%$ \\
\hline WETF & PC-2 & 0.54 & $\begin{array}{c}12 \% \text { Independent } \\
22 \% \text { Coupled }\end{array}$ \\
\hline RLWTF \& WCRRF & PC-2 & 0.54 & $<<1 \%$ \\
\hline TWISP & PC-2 & 0.54 & $12 \%$ \\
\hline
\end{tabular}

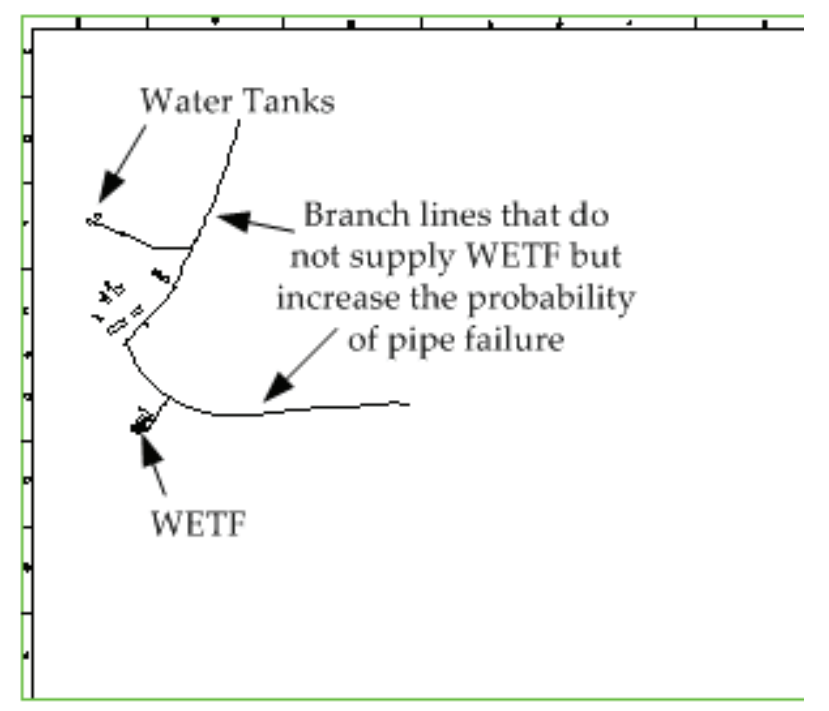

Water Distribution System with CLOSED Isolation Valves, 11,925 feet of piping $\mathrm{P}_{\mathrm{f}}=11 \%$ for PC-2 PGV

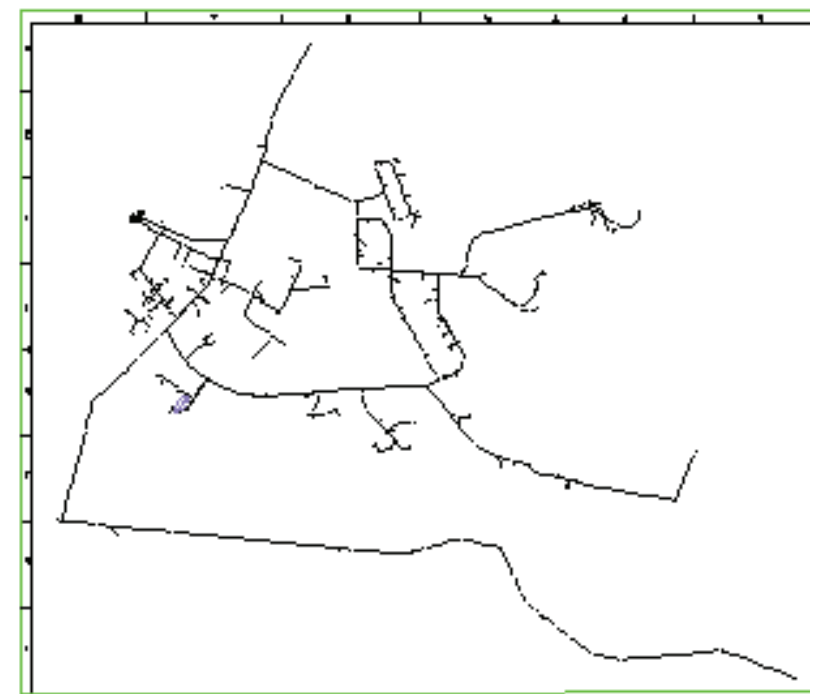

Water Distribution System with OPEN Isolation Valves, 93,127 feet of piping $\mathrm{P}_{\mathrm{f}}=73 \%$ for PC-2 PGV

Figure 14. TA-16 water distribution system. 
The results of this assessment are very sensitive to the assumption that isolation valves are closed, limiting the length of the piping in the water supply system to the critical facility. Additionally, the probabilities of failure in Table 16 can be reduced by installing isolation valves to remove unnecessary branch lines from the tank to the facility water distribution system.

As discussed previously, the hazard resulting from permanent ground deformation and fault offset are not significant for PC-2 SSC. Thus, the probability of pipe failure caused by permanent ground deformation and fault offset are not considered.

\subsection{Tank Failure}

The tank fragility curves in Table 9 are plotted versus peak spectral acceleration in Figures 15 and 16. As seen in Figure 15, failure of an unanchored tank is dominated by buckling that leads to a loss of contents. The combined probability of failure is calculated using Equation 7.

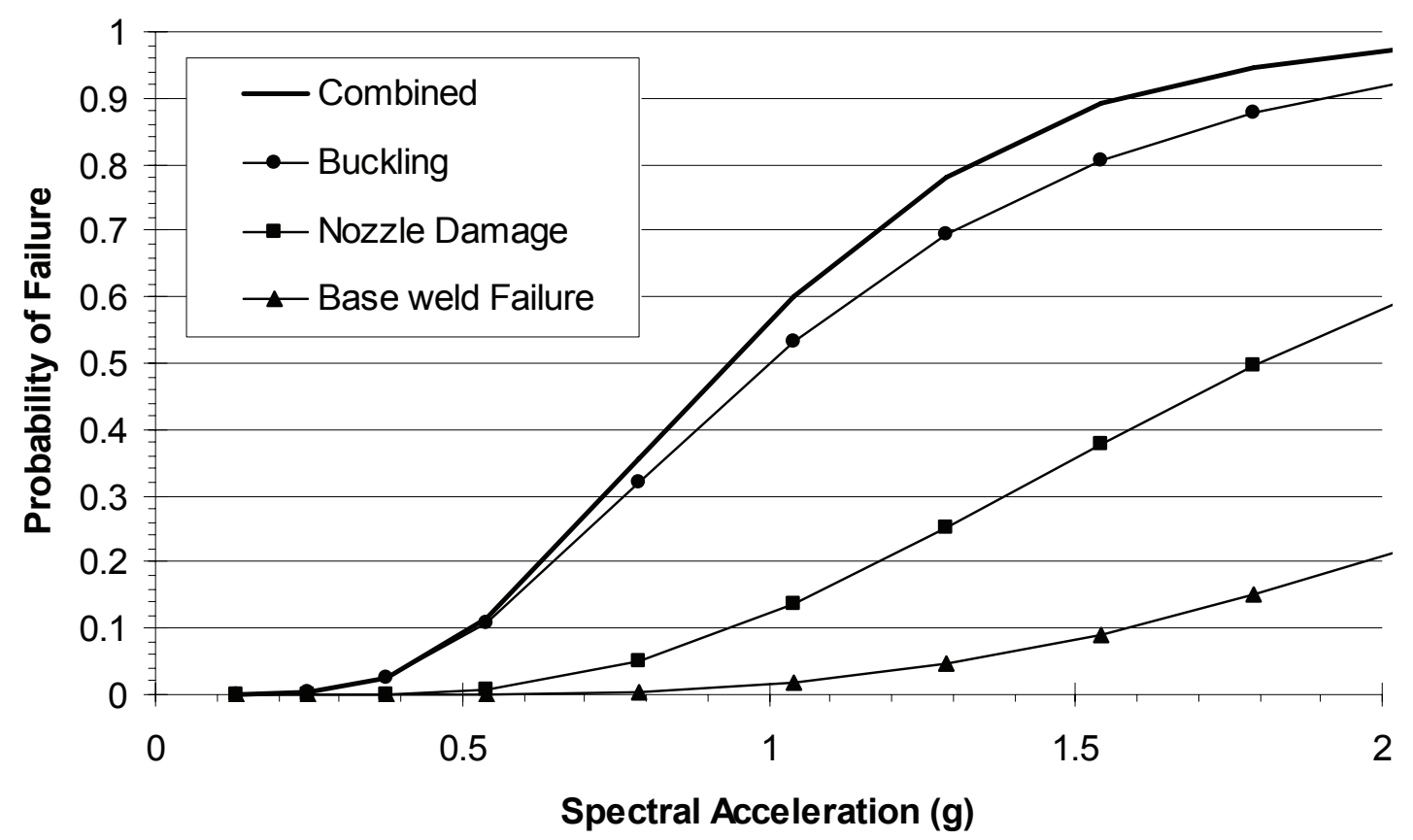

Figure 15. Fragility for unanchored steel tank 100,000 to 2,000,000 gallons

(CMR, TWISP, WETF x 2). 


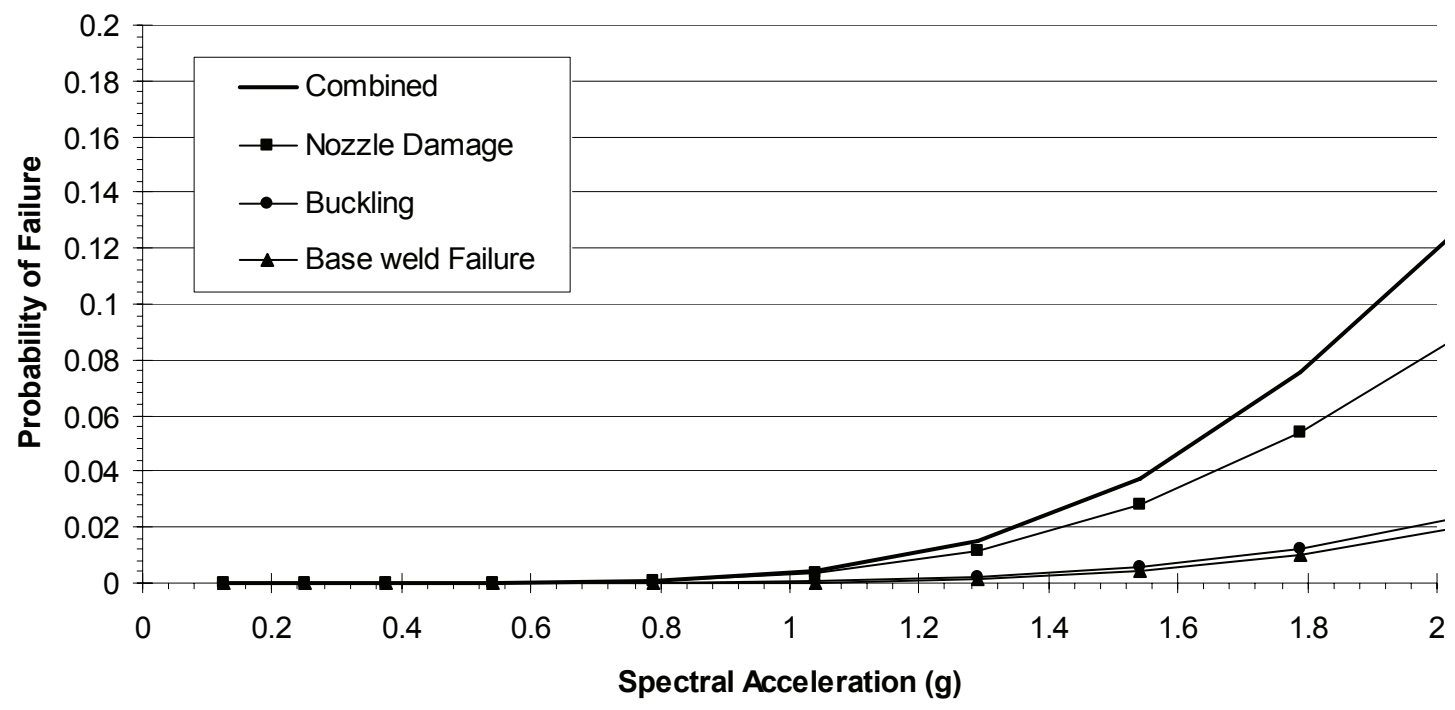

Figure 16. Fragility curve for anchored steel tank 100,000 to 2,000,000 gallons (RLWTF and WCRRF).

The 0.2-second spectral acceleration in Figure 10 is taken as the peak spectral acceleration for the 7- and 8-hz tank failure modes. This is consistent with the broad IBC spectral shape. Consistent with the IBC, two-thirds of the MCE 2,500-year ground motion is $2 / 3(0.81)=0.54 \mathrm{~g}$; which matches the $\mathrm{S}_{\mathrm{DS}}$ specified by the LANL ESM. The spectral acceleration for the $0.06 \mathrm{~g} \mathrm{CMR} \mathrm{DBE}$ is determined from Figure 10 and has the same exceedance probability as the $0.06 \mathrm{~g}$ DBE.

The probability of tank failure is extracted from Figures 14 and 15 and summarized in Table 16 for various tanks. Two unanchored tanks feed WETF. Because both tanks feed the same distribution system, then they may be coupled, and the failure of one tank could result in the loss of both tanks contents. The probability of failure for the coupled tanks was calculated with Equation 7 using $2 \times 3$ failure mechanisms (i.e. buckling-tank A, buckling-tank B, etc.).

\section{System Failure Frequencies}

Individual component failure frequencies are combined to establish system fragilities. System fragilities are then convolved with the seismic hazard to obtain the probability of failure.

\subsection{Conditional Probability of Failure}

The conditional probabilities of failure contained in this assessment are based upon the earthquakes in Table 1. The conditional probabilities of failure are summarized in Table 17 below. Conditional failure probabilities for piping and tank components are combined with Equation 7. 
Table 17. Summary of Conditional Probabilities of Failure for the Acceptance Criteria Earthquake

\begin{tabular}{|l|c|c|c|c|}
\hline \multirow{2}{*}{ Facility } & \multirow{2}{*}{$\begin{array}{c}\text { Acceptance } \\
\text { Criteria }\end{array}$} & \multicolumn{3}{|c|}{ Conditional Probability of Failure, $\left.\mathrm{P}_{\mathrm{f}}\right|_{\mathrm{DBE}}$} \\
\cline { 3 - 5 } & & Piping & Tank & Combined \\
\hline CMR & $0.06 \mathrm{~g}$ DBE & $1 \%$ & $<<1 \%$ & $1 \%$ \\
\hline WETF & PC-2 & $11 \%$ & $\begin{array}{c}12 \% \text { Independent } \\
22 \% \text { Coupled }\end{array}$ & $\begin{array}{c}22 \% \text { Independent } \\
31 \% \text { Combined }\end{array}$ \\
\hline RLWTF \& WCRRF & PC-2 & $10 \%$ & $<<1 \%$ & $18 \%$ \\
\hline TWISP & PC-2 & $22 \%$ & $12 \%$ & $31 \%$ \\
\hline
\end{tabular}

\subsection{System Fragility Curves}

The components in each system are identified in Table 18. The four WETF cases are to investigate the effects of coupled versus independent tanks and to investigate the effects of closing isolation valves.

Table 18. Components for Each System Analyzed

\begin{tabular}{|c|c|c|c|c|c|c|c|}
\hline & \multicolumn{7}{|c|}{ System } \\
\hline & \multirow[b]{2}{*}{ CMR } & \multirow{2}{*}{$\begin{array}{l}\text { RLWTF \& } \\
\text { WCRRF }\end{array}$} & \multirow[b]{2}{*}{ TWSIP } & \multicolumn{4}{|c|}{ WETF Case } \\
\hline & & & & \#1 & $\# 2$ & \#3 & $\# 4$ \\
\hline Isolation Valves & Closed & Closed & Closed & Closed & Closed & Open & Open \\
\hline \multicolumn{8}{|l|}{ Components } \\
\hline \multicolumn{8}{|c|}{ Water Distribution Piping } \\
\hline CMR & 1 & & & & & & \\
\hline RLWTF & & 1 & & & & & \\
\hline TWSIP & & & 1 & & & & \\
\hline \multicolumn{8}{|l|}{ WCRRF } \\
\hline WETF & & & & 1 & 1 & & \\
\hline \multicolumn{4}{|c|}{ WETF w/Open Isolation Valves } & & & 1 & 1 \\
\hline \multicolumn{8}{|l|}{ Unanchored Tanks } \\
\hline Base Weld Failure & 1 & & 1 & 2 Coup. & 2 Ind. & 2 Coup. & 2 Ind. \\
\hline Nozzle Damage & 1 & & 1 & 2 Coup. & 2 Ind. & 2 Coup. & 2 Ind. \\
\hline Buckling & 1 & & 1 & 2 Coup. & 2 Ind. & 2 Coup. & 2 Ind. \\
\hline \multicolumn{8}{|l|}{ Anchored Tanks } \\
\hline Base Weld Failure & & 1 & & & & & \\
\hline Nozzle Damage & & 1 & & & & & \\
\hline Buckling & & 1 & & & & & \\
\hline
\end{tabular}


The component fragility curves in Figures 15 and 16 are converted to the PGV ground motion parameter by applying Equation 9 to the abscissa. For each value of the ground motion parameter, the individual component failure probabilities are combined using Equation 7, resulting in the system fragility curves shown in Figure 17.

As expected, the WETF cases with open isolation valves have the highest probability of failure at a given level of ground motion. RLWTF has the lowest probability of failure for a given level of ground motion because it has an anchored tank that has a negligible contribution to the seismic hazard. The RLWTF system curve is almost identical to the pipe failure fragility curve in Figure 13. The remaining systems are ordered in terms of decreasing length of distribution piping.

\subsection{Annual Probability of Failure}

The annual probability of failure of the water-distribution systems, shown in Table 19, is determined by the convolution of the seismic-hazard and system-fragility curves using Equation 8, with the variables:

$\mathrm{P}_{\mathrm{F} / \mathrm{a}}$ is the system fragility curve shown in Figure 17,

$\mathrm{dP}_{\mathrm{F} / \mathrm{a}} / \mathrm{da}$ is the conditional probability density function that describes the probability of failure $\left(\mathrm{PF}_{\mathrm{F}}\right)$, given an earthquake in the range da; $\mathrm{dP} / \mathrm{F} / \mathrm{da}$ is determined numerically from the data in Figure 17, and

$\mathrm{H}(\mathrm{a})$ is a piecewise log-log seismic hazard curve labeled "Hazard Due to PGV" in Figure 12.

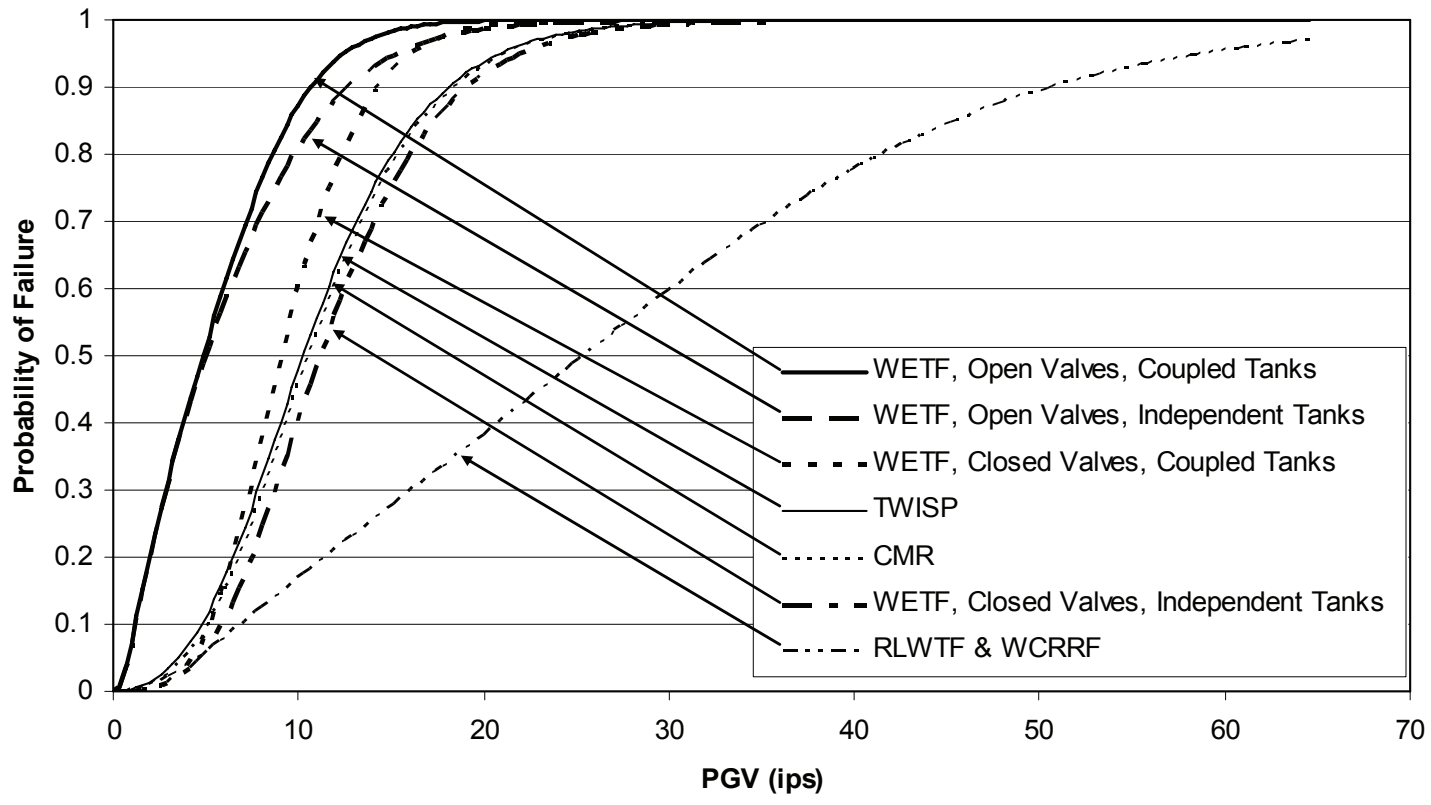

Figure 17. System fragility curves. 
Table 19. Summary of Water Distribution System Annual Failure Probabilities

\begin{tabular}{|l|l|l|c|c|}
\hline \multicolumn{1}{|c|}{ System } & $\begin{array}{c}\text { Isolation } \\
\text { Valve }\end{array}$ & \multicolumn{1}{|c|}{ Water Tank } & $\begin{array}{c}\text { Annual Failure } \\
\text { Probability }\end{array}$ & $\begin{array}{c}\text { Return } \\
\text { Period }\end{array}$ \\
\hline CMR & Closed & 1 Unanchored & $9.2 \times 10^{-4}$ & 1,100 \\
\hline RLWTF and WCRRF & Closed & 1 Anchored & $4.8 \times 10^{-4}$ & 2,100 \\
\hline TWSIP & Closed & 1 Unanchored & $10 . \times 10^{-4}$ & 1,000 \\
\hline WETF-1 & Closed & 2 Unanchored, Coupled & $9.7 \times 10^{-4}$ & 1,000 \\
\hline WETF-2 & Closed & 2 Unanchored, Indep. & $7.8 \times 10^{-4}$ & 1,300 \\
\hline WETF-3 & Open & 2 Unanchored, Coupled & $43 . \times 10^{-4}$ & 230 \\
\hline WETF-4 & Open & 2 Unanchored, Indep. & $42 . \times 10^{-4}$ & 240 \\
\hline
\end{tabular}

The integration in Equation 8 is carried out numerically from a minimum value of 0.01 to twice the maximum PGV. The hazard data, H(a), are extrapolated between 0.01 and the minimum value. Limits of integration smaller than 0.01 or larger than $2 \mathrm{Max}[\mathrm{PGV}]$ do not affect the value of Pf.

\subsection{Reconciliation of Conditional Failure Probability and Annual Failure Probability}

The TWISP water distribution piping has a $22 \%$ chance of failure for the IBC ground motion (Table 16). The IBC ground motion has a return period of about 1,400 years and is the PC-2 design-basis earthquake. The basic safety objective of DOE-STD-1020 is to have no more than a $10 \%$ probability of failure at 1.5 times the design-basis ground motion. The TWISP water distribution piping clearly does not meet this criterion.

However, the DOE-STD-1020 basic safety objective was developed [10] for SSC with lognormal standard deviations between 0.3 and 0.6 , but ALA specifies a lognormal standard deviation for water distribution systems of 1.15. Thus, the water distribution system in this assessment is outside the bounds used to develop the basic safety objective.

A plot of the TWISP water distribution piping Probability Density Function (PDF) is shown in Figure 18. The PDF is lognormally distributed with a median value of 24.44 ips and a logarithmic standard deviation of 1.15. Also shown are distributions with logarithmic standard deviations of 0.3 and 0.6 . Note that the distribution with $\sigma_{\operatorname{lnk}}=1.15$ is much more sensitive to small values of PGV than the other two distributions. Thus, the large logarithmic standard deviation makes the water distribution piping probability of failure more sensitive to small PGV than considered in the development of DOESTD-1020. 


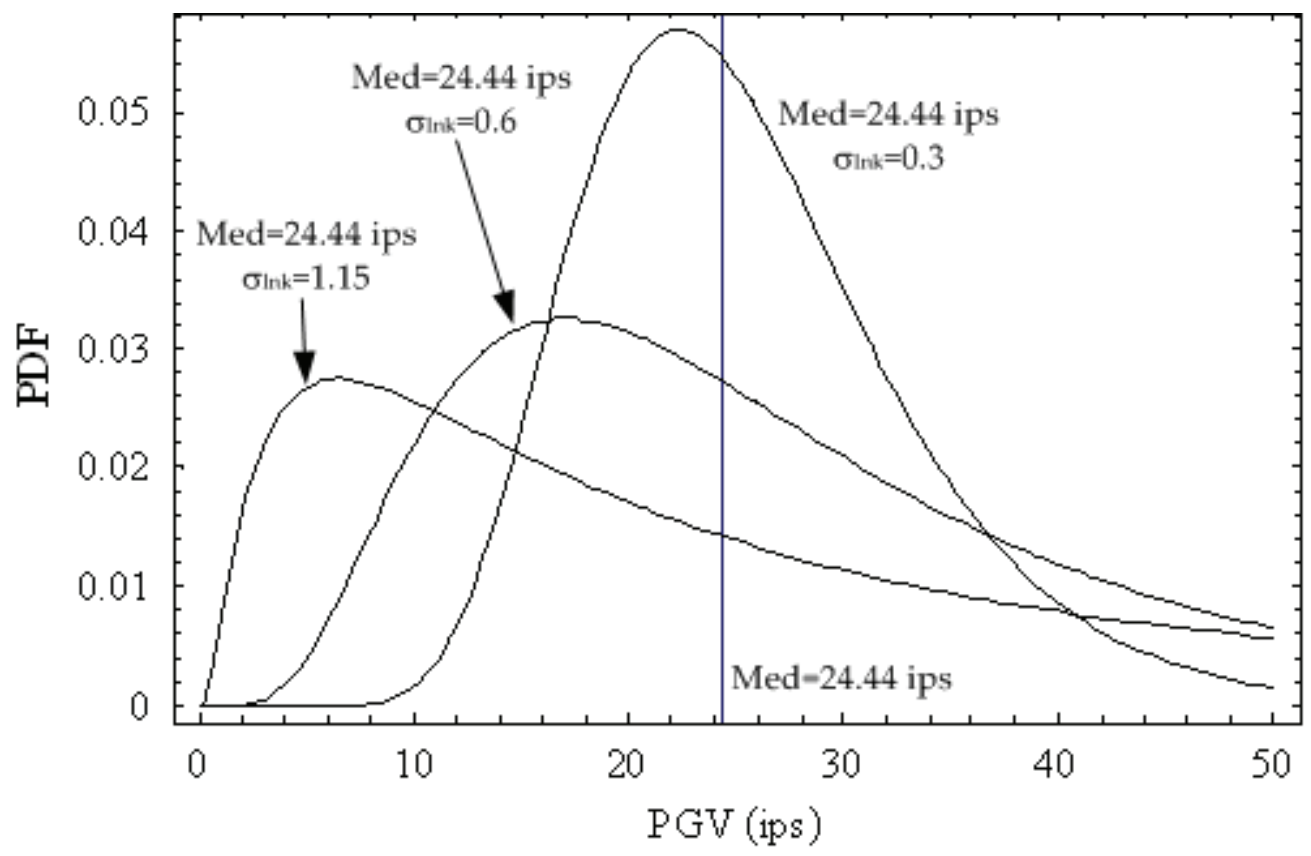

Figure 18. TWISP water distribution system probability density function.

The criteria in DOE-STD-1020 are also based on seismic hazard curves with a slope parameter, $\mathrm{K}_{\mathrm{H}}$, between 1.5 and 4.0. The slope parameter for the LANL hazard curve for small PGV, which dominates the probability of failure calculation, is $\mathrm{K}_{\mathrm{H}}=7.87 / 1.14=6.9$. The difference in these two curves is shown graphically in Figure 19. From Figure 19 it can be seen that the $K_{H}=4$ hazard curve has a higher exceedance probability, which will increase the annual probability of failure for SSC that are sensitive to PGV less than about 8 ips. The TWISP water distribution piping has an annual component probability of failure of $5.6 \times 10^{-4}$ (1,700-year return period) using the LANL hazard curve. Using the $\mathrm{K}_{\mathrm{H}}=4$ hazard curve in Figure 17, the annual probability of failure increases to $1.3 \times 10^{-3}$ (720-year return period).

At first glance, the TWISP water distribution piping annual probability of failure of $5.6 \times 10^{-4}$ does not appear to be consistent with a $22 \%$ chance of failure given the IBC ground motion. However, it has been shown that

1. The low probability of failure is due to the unusual slope of the LANL hazard curve for small PGV.

2. The large logarithmic standard deviation skewed the capacity PDF and increased the contribution of small PGV to the annual probability of failure. 


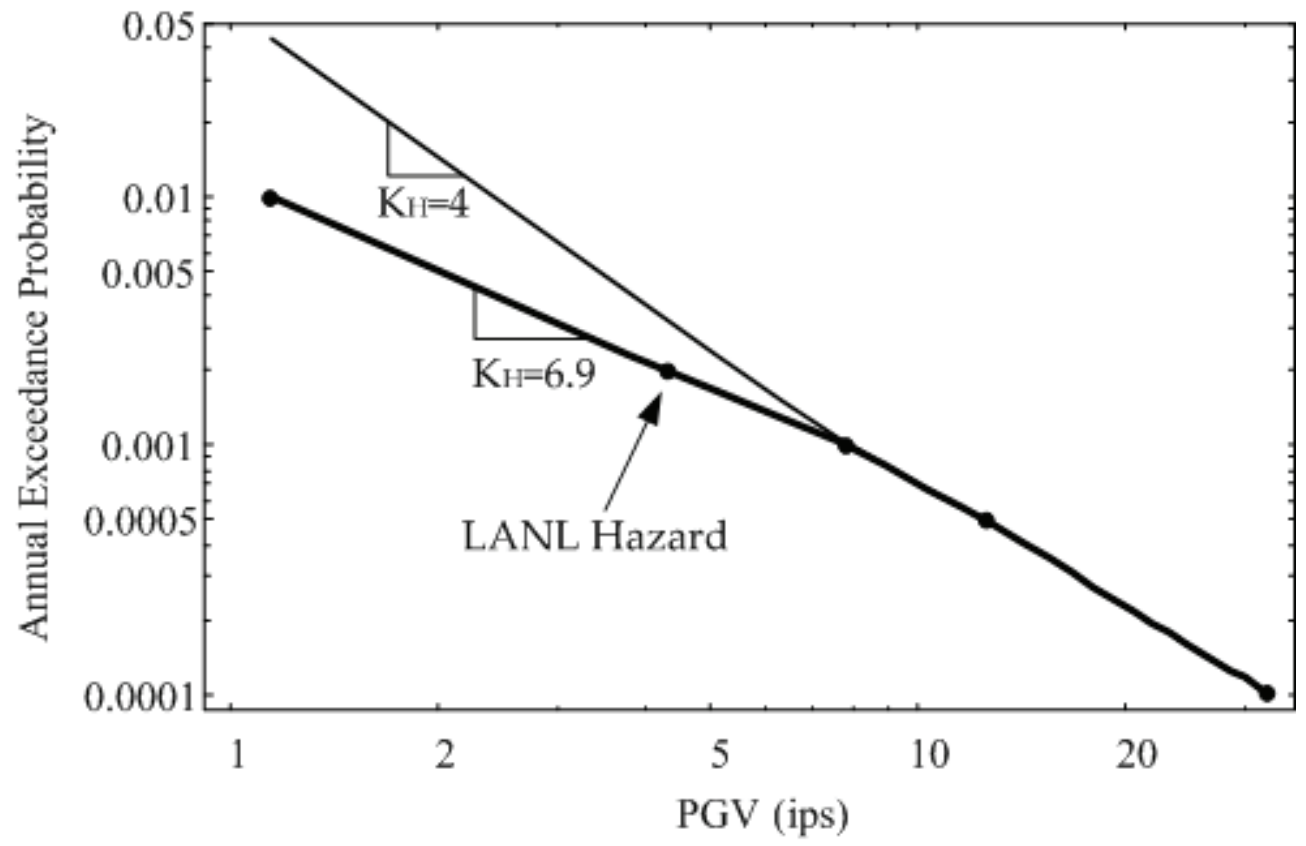

Figure 19. Comparison of LANL hazard and $K_{H}=4$ hazard.

\subsection{Potential Impact of the DRAFT 2007 Probabilistic Seismic Hazards Analysis}

The preceding results are based on the 1995 PSHA. As of January 2007, the 1995 PSHA is the analysis of record that defines the level of seismic input at LANL.

An update to the 1995 PSHA is being prepared, and it is anticipated that this update will be implemented in 2007. Therefore, this update will be referred to as the DRAFT 2007 PSHA.

Preliminary and unverified results from the DRAFT 2007 PSHA suggest that the peak ground velocity may increase by a factor of 1.9 for a 2,500-year event. This increase reflects (1) a general increase in the level of ground acceleration; and (2) a significant increase in the low-frequency content of the ground motion. Peak ground velocities are currently not available for other return periods.

An estimate of the potential impact of the DRAFT 2007 PSHA on the water system failure frequency is obtained by uniformly increasing the peak ground velocity in Figure 12 by a factor of 1.9 and recalculating the system failure frequencies in the preceding section. The resulting annual failure frequency is roughly twice the values shown in Table 20. 
Table 20. Summary of Water Distribution System Annual Failure Probabilities

\begin{tabular}{|l|l|l|c|c|c|}
\hline System & $\begin{array}{c}\text { Isolation } \\
\text { Valve }\end{array}$ & $\begin{array}{c}\text { Water } \\
\text { Supply } \\
\text { Tank }\end{array}$ & $\begin{array}{c}\text { Annual Failure } \\
\text { Probability, } \mathbf{P}_{\mathbf{F}}\end{array}$ & $\begin{array}{c}\text { Target Performance } \\
\text { Goal for Existing SSC }\end{array}$ & $\begin{array}{c}\text { Meets } \\
\text { Goal }\end{array}$ \\
\hline CMR & Closed & $\begin{array}{l}1 \\
\text { Unanchored }\end{array}$ & $0.92 \times 10^{-3}$ & $0.06 \mathrm{~g}$ PGA & Yes \\
\hline RLWTF & Closed & 1 Anchored & $0.48 \times 10^{-3}$ & PC-2, $\mathrm{P}_{\mathrm{F}} \leq 1 \times 10^{-3}$ & Yes \\
\hline TWISP & Closed & $\begin{array}{l}1 \\
\text { Unanchored }\end{array}$ & $1.00 \times 10^{-3}$ & PC-2, $\mathrm{P}_{\mathrm{F}} \leq 1 \times 10^{-3}$ & Yes \\
\hline WETF-1 & Closed & $\begin{array}{l}2 \\
\text { Unanchored, } \\
\text { Coupled }\end{array}$ & $0.97 \times 10^{-3}$ & PC-2, $\mathrm{P}_{\mathrm{F}} \leq 1 \times 10^{-3}$ & Yes \\
\hline WETF-2 & Closed & $\begin{array}{l}2 \\
\text { Unanchored, } \\
\text { Independent }\end{array}$ & $0.78 \times 10^{-3}$ & PC-2, $\mathrm{P}_{\mathrm{F}} \leq 1 \times 10^{-3}$ & Yes \\
\hline WETF-3 & Open & $\begin{array}{l}2 \\
\text { Unanchored, } \\
\text { Coupled }\end{array}$ & $4.3 \times 10^{-3}$ & PC-2, $\mathrm{P}_{\mathrm{F}} \leq 1 \times 10^{-3}$ & No \\
\hline WETF-4 & Open & $\begin{array}{l}2 \\
\text { Unanchored, } \\
\text { Independent }\end{array}$ & $4.2 \times 10^{-3}$ & PC-2, $\mathrm{P}_{\mathrm{F}} \leq 1 \times 10^{-3}$ & No \\
\hline
\end{tabular}

DRAFT 2007 PSHA spectral acceleration hazard curves suggest that the probability of exceedance for small events has decreased while the probability of exceedance for large events has increased. Because spectral acceleration and peak ground velocity are related, then the peak ground velocity hazard curve should have a similar behavior. Thus, uniformly increasing the peak ground velocity in Figure 12 introduces conservatism into the failure frequency estimate.

Therefore, the DRAFT 2007 PSHA is estimated to increase the probability of water distribution system failure by a factor of 2 or less.

\section{Summary and Conclusions}

In a gap analysis of DOE-G-420.1-2, the Safety Basis Office determined five facilities that have fire suppression systems providing a safety function during natural phenomena events. The purpose of this assessment was to determine how these systems would perform with respect to seismic hazards.

The methodology used in this assessment was developed by the ALA, a cooperative organization founded by FEMA and the ASCE. The methodology is based on observed water-distribution failures following earthquakes. The observed failures were culled from 
utility repair records. It is important to note that the utility crews were focused on returning the water system to service and that some records are incomplete. Thus, there were repairs made that are not reflected in the empirical data base. On the conservative side, damage ranged from completely severed lines to functional lines that leaked. Additionally, some repairs were repeated and recorded multiple times, at locations where the ground continued to creep following the earthquake. It is our judgment that these effects are offsetting and that the ALA methodology represents the best estimate of pipe failure currently available.

Some observed failure components, such as liquefaction and fault displacement, are not significant at LANL for PC-2 ground motions and were omitted from this assessment.

Individual component fragilities are combined to obtain system fragilities that are convolved with the facility seismic hazard to determine the failure frequency. Failure frequencies for various systems are summarized and compared to the DOE-STD-1020 performance goals in Table 20.

The annual probability of failure is compared to the PC-2 performance goal in Appendix B of DOE-STD-1020. The performance goal has been reduced by a factor of two according to the existing facility evaluation criteria in DOE-STD-1020. All of the systems meet the target performance goal if their isolation valves are closed to dedicate the water distribution system to that facility and remove leaking branch lines.

The acceptance criterion for CMR is to survive an earthquake with a $0.06 \mathrm{~g}$ peak ground acceleration. The criterion for CMR is relaxed from PC-2, based on the condition of the facility and safety-basis commitments. The CMR water distribution system also meets the PC-2 target performance goal if existing isolation valves are closed to dedicate the water distribution system to that facility and remove leaking branch lines.

These results are highly dependent on the length of piping in the distribution system that can break. The results for CMR, RLWTF, TWISP, and WCRRF assume that existing isolation valves will be closed and that all piping that is not essential for supplying the nuclear facility from the distribution system will be removed.

- Up to 48 (CMR) isolation valves per facility may need to be closed to dedicate the water-distribution system to a specific facility and remove leaking branch lines.

- At this time, there is no protocol in emergency response that requires closing isolation valves.

- Closing the isolation valves will negate fire fighting capability at nonnuclear facilities.

- The potential for and consequences of closing the wrong isolation valve were not considered in this assessment.

The probabilities of failure for WETF were calculated for cases of both open and closed isolation valves. Leaving the isolation valves open at WETF increases the probability of failure by roughly a factor of five. Similar increases for CMR, RLWTF, TWISP and 
WCRRF are likely. A five-fold increase in failure probability would result in these facilities not meeting the PC-2 target performance goals.

WETF is supplied by two water tanks, and the failure of one tank may result in the loss of the other tanks' contents. Thus, the WETF results consider cases with two independent tanks and two coupled tanks. The coupled vs. independent tank issue is insignificant compared to the position of the isolation valves.

\section{References}

1. D. Satterwhite, "Site Supplied Safety Systems," PS-4P05-056, 2005.

2. LANL, "LANL Gap Analysis and Line-by-Line Safety Impact Assessment for Implementation of DOE G 420.1A, DOE G 420.1-1, and DOE G 420.1-2," Los Alamos National Laboratory report RPT-ENG-001, RO, March 2005.

3. www.americanlifelinesalliance.org.

4. ASCE American Lifelines Alliance, "Seismic Fragility Formulations for Water Systems," American Society of Civil Engineers, April 2001.

5. U.S. DOE, "Natural Phenomena Hazards Design and Evaluation Criteria for Department of Energy Facilities," Department of Energy standard DOE-STD10202002.

6. KSL, Utilities Operating Instruction Number 60-00-125, Rev. 0, November 20, 2000.

7. Woodward-Clyde, "Final Report: Seismic Hazard Evaluation of the Los Alamos National Laboratory," February 1995.

8. "Final Report, Probabilistic Seismic Hazard Analyses for Surface Displacement at Woodward-Clyde, TA-3 Los Alamos National Laboratory," July 1998

9. Woodward-Clyde, "Final Report, Probabilistic Seismic Hazard Analyses for Surface Displacement at TA-16 Los Alamos National Laboratory," January 2001

10. U.S. DOE, UCRL-CR-111478, "Basis for Seismic Provisions of DOE-STD1020," Department of Energy document, LLNL, Revision 1,1994.

11. Kennedy, R. P., "Overview of Methods for Seismic PRA and Margin Analysis Including Recent Improvements," Proceedings of the OECD-NEA Workshop on Seismic Risk, Tokyo Japan, August 1999.

12. International Code Council, IBC, International Building Code, 2003.

13. LANL, Engineering Manual Standards, Chapter 5, Structural, Rev. 2, June 1, 2006.

14. Steve L. Kramer, "Geotechnical Earthquake Engineering," Prentice Hall, 1996.

15. http://www.ce.washington.edu/ liquefaction $/ \mathrm{html} / \mathrm{main} . \mathrm{html}$.

16. C.I. Costantino and T.W. Houston, "Evaluation of Slope Stability at the Biosafety Level 3 Laboratory," Los Alamos National Laboratory report LLA-14168, 2005. 
This report has been reproduced directly from the best available copy. It is available electronically on the Web (http://www.doe.gov/bridge).

Copies are available for sale to U.S. Department of Energy employees and contractors from:

Office of Scientific and Technical Information

P.O. Box 62

Oak Ridge, TN 37831

(865) 576-8401

Copies are available for sale to the public from: National Technical Information Service

U.S. Department of Commerce

5285 Port Royal Road

Springfield, VA 22161

(800) 553-6847 
- Los Alamos NATIONAL LABORATORY 